\title{
Compensation Benchmarking, Leapfrogs, and the Surge in Executive Pay ${ }^{1}$
}

\author{
Thomas A. DiPrete and Gregory M. Eirich \\ Columbia University \\ Matthew Pittinsky \\ Arizona State University
}

Scholars frequently argue whether the sharp rise in chief executive officer (CEO) pay in recent years is "efficient" or is a consequence of "rent extraction" because of the failure of corporate governance in individual firms. This article argues that governance failure must be conceptualized at the market rather than the firm level because excessive pay increases for even relatively few CEOs a year spread to other firms through the cognitively and rhetorically constructed compensation networks of "peer groups," which are used in the benchmarking process to negotiate the compensation of CEOs. Counterfactual simulation based on Standard and Poor's ExecuComp data demonstrates that the effects of CEO "leapfrogging" potentially explain a considerable fraction of the overall upward movement of executive compensation since the early 1990s.

\section{INTRODUCTION}

Income inequality has been rising in the United States since the late 1970s, with most of the increase since the early 1990s being at the top of the income distribution. Some attribute the increase primarily to technical factors that have increased demand for education, but others argue that

\footnotetext{
${ }^{1}$ This research was supported by National Science Foundation grant SES-0648138 and by the Russell Sage Foundation. Previous versions of this article were presented at the August 2008 meeting of the Research Committee 28 (Social Stratification) of the International Sociological Association at Stanford University, at the Center for the Study of Inequality at Cornell University in September 2008, in the management seminar series of the Columbia Business School in November 2008, and at the University of Bielefeld in May 2008. We thank Stephen Morgan, Howard Aldrich, Neil Fligstein, and the AJS reviewers for helpful comments and suggestions. Please direct correspondence to Thomas A. DiPrete, Department of Sociology, Columbia University, 606 West 122nd Street, New York, New York 10027. E-mail: tad61@columbia.edu
}

(C) 2010 by The University of Chicago. All rights reserved.

0002-9602/2010/11506-0001\$10.00

AJS Volume 115 Number 6 (May 2010): 1671-1712 


\section{American Journal of Sociology}

this explanation is implausible: technical change is global in character, and yet earnings inequality rose much more rapidly in the United States than in other industrialized countries. This anomaly has led scholars to argue that the explanation for inequality trends must involve institutional arrangements that determine the setting of pay (Ebbinghaus and Kittel 2005; Kenworthy 2007), the terms of employment (Maurin and PostelVinay 2005; DiPrete et al. 2006), and, more abstractly, the level of "rent" that can be extracted from specific classes and occupations (Sorensen 2000; Weeden 2002; Morgan and Tang 2007). ${ }^{2}$

These debates about labor market trends in general mirror debates about the pay of American corporate executives, which has increased rapidly even as earnings in general have risen at the top of the American distribution. Some scholars argue that corporations have bid up executive compensation according to the rules of "superstar" labor markets in a manner that is consistent with a "shareholder value" model of corporate governance. Others counter that chief executive officer (CEO) compensation rose so rapidly because CEOs gained too much power over the setting of their own pay. Defenders of the shareholder value theory cite positive firm-level correlations between pay and performance. Proponents of the managerial power theory call attention to numerous characteristics of compensation practices that appear inconsistent with efficient market practices. Defenders respond that the large increase in compensation during the 1990s occurred even as corporate governance in general appeared to be tightening, not loosening. Critics find plausible evidence of a correlation between the quality of governance in the firm and the compensation of its executives net of performance and other market-relevant factors. Defenders point to other evidence that questions the impact of firm-level governance on the rising compensation trend.

Aside from the tremendous cultural power of the shareholder value model, the debate remains unresolved in large part because opponents argue on different planes. Proponents of the "pay for performance" model see the matching of executive talent and firm characteristics as essential to the production of shareholder value. They see pay being set by the environment, that is, by a market that defines the executive's true "opportunity cost" and therefore his market wage (zero opportunity cost equals zero rent). Proponents of the managerial power model assert that "above-market" pay arises from governance failures at individual firms.

\footnotetext{
${ }^{2}$ The standard definition of economic rent is the difference between the returns to a given factor of production and its opportunity cost, i.e., its returns in the best alternative. Those who win access to high-paying positions that are in limited supply can be paid much better in these positions than they could elsewhere, which implies a high "rent" component of their earnings.
} 
Neither of these positions adequately captures the implications of the interaction between firm and environment, which provides a structural basis for rent extraction. We favor a third explanation that emphasizes the systemic implications of managerial power. According to this third explanation, the complexity and dynamism of compensation comparison groups produce a mechanism by which governance failures in individual firms propagate through corporate networks via the normal workings of the benchmarking system to raise executive salaries.

We show that a small and shifting fraction of CEOs have regularly been able to "leapfrog" their compensation benchmarks by moving to the right tail of the benchmark distribution and get larger than normative compensation increases, even after taking job mobility and executive performance into account. These events produce subsequent "legitimate" pay increases for others and potentially explain an important fraction of the overall upward movement of executive compensation over the past 15 years. Aside from being consistent with the the concept of "strategic conformity" that is frequently postulated by economic sociology institutionalists, this result implies that the concept of firm-level governance of corporate compensation is inherently flawed; the linkages among firms produced by the benchmarking process guarantee that firm-level governance failure becomes a factor in the environment of other firms. In other words, rent extraction takes place even when CEOs are paid their "market wage" as established by competitive benchmarks. This argument supports the recent attention in the stratification literature to rent extraction as a manifestation of occupational power rather than an outcome of the bargaining power of individual workers.

\section{INEQUALITY, RENT EXTRACTION, AND THE GOVERNANCE OF MARKETS}

Theories for the rapid rise in American earnings inequality fall into two basic camps. One emphasizes rising demand for educational skills that is driven largely by technical change and a failure of the supply of collegeeducated workers to keep up (Katz and Autor 1999; Goldin and Katz 2008). Another emphasizes changes in the ability of workers in different occupations to extract rents. Rent seeking included what Sorensen (1996, 2000) called the "zero-sum competition for positional goods" (2000, p. 1544), where the quasi "zero-sum" character comes from "social closure" processes such as licensing that restrict occupational access (Weeden 2002). Rent seeking also included the competition between owners and employees for gains obtained from favorable market positions produced by a specific combination of capital and labor inputs. For example, Sorensen 
American Journal of Sociology

(2000) saw executive pay as a form of rent; executives used their control of productive assets such as cash flows and information to manipulate corporate governance processes that ostensibly protect the interests of shareholders. ${ }^{3}$ Changes in the relative strength of owners and employers could increase rents going to employees or decrease them. Thus, Sorensen speculated that selective destruction of rent for many labor market positions was raising inequality in America, which received empirical support from Morgan and Tang (2007). ${ }^{4}$

While the social closure literature has mostly focused on the control of access to desirable positions throughout the labor market, the question of how pay is set for executive positions in large organizations is of equal importance, both because of what it says about income inequality and because it provides a strategic research site for studying how the distribution of rents relates to the efficiency of markets. The fundamental theoretical question can be stated simply: Does lofty and historically rising executive compensation represent a failure of governance, which reduces shareholder value and produces economic inefficiency alongside high economic rents? Or does it enhance shareholder value through the optimal matching of specific labor assets (rare entrepreneurial and managerial talent) and the capital assets of corporations?

The classical framing of the governance question surrounding executive compensation is the theory of managerialism formulated by Berle and Means (1932), which argued that managers act in their own interests at the expense of the interests of shareholders. The theory of shareholder value (also referred to as the "contractarian" approach to corporate governance; see Davis 2005) rejected this conclusion. According to the theory of shareholder value, financial markets disciplined managers to act in the interest of shareholders, and labor markets disciplined firms to compensate executives according to their performance (Fama 1980). ${ }^{5}$ The theory that managers should run corporations to create shareholder value became the dominant corporate ideology during the 1980s (Davis 2005; see also Fligstein 1990) and was the basis for the movement to increase the weight of equity and other "at-risk" compensation in executive compensation packages in order to align their interests more closely with those of shareholders

${ }^{3}$ The possibility that executive compensation involves rents has been recognized by at least some economists for many decades (Marshall 1920; Hicks 1948; see especially Roberts 1956)

${ }^{4}$ Morgan and Tang found that the interindustry variance in wages declined from 1983 to 2001; the relative earnings of those at the bottom of the class distribution have also declined.

${ }^{5}$ The theory of shareholder value received early empirical support from research showing that manager-controlled firms performed as well as owner-controlled firms (Demsetz and Lehn 1985; Short 1994). 
(Useem 1993). The competing positions of managerialism and the theory of shareholder value continue to frame the contemporary debate.

A key theoretical issue in the debate over executive compensation concerns the distinction between the questions "where does governance come from?" and "how well does governance work?" From the perspective of the theory of shareholder value, these questions amount to the same thing; that is, the answer to "where does governance come from?" is "the market," and the answer to "how well does governance work?" is that "market discipline produces optimal shareholder value." Economic sociology sees these questions as fundamentally separate. As argued in recent reviews of this literature (Davis 2005; Fligstein and Choo 2005; Fligstein and Dauter 2007), much of the sociological literature concerns the documentation that corporate governance responds to institutional as well as market imperatives, with a principal institutional force being the historically changing set of cultural conceptions about how markets should work (Fligstein 2002). Bebchuk, Fried, and Walker (2002), meanwhile, question from a legal perspective the effectiveness of corporate governance in their critique of "optimal contracting theory" via their core assertion that "there is no contract that would perfectly align the interests of managers and shareholders" (p. 751).

The failure of optimal contracting theory, according to Bebchuk et al. (2002; see also Bebchuk and Fried 2004), stems from the lack of arm'slength bargaining between executives and boards and the power of managers to legitimize and otherwise "camouflage" the extraction of rents from the corporation. ${ }^{6}$ Evidence for rent extraction in the managerial power literature takes two forms. One form of evidence consists of behavior that can be accounted for by a managerial power theory but cannot readily be accounted for by an optimal contract theory, including $(a)$ the general failure of companies to index stock options so that executives would not be rewarded for general stock price rises unrelated to own-firm performance (even as they tend to protect executives against "bad-luck" events that affect share prices), (b) the general failure of companies to award "out-of-the-money" options (even though empirical evidence exists that such options would boost shareholder value), $(c)$ the resetting of option exercise prices when the options move out of the money (even when the stock declines because of poor firm performance), $(d)$ the allowing of executives to hedge against equity exposure (thereby undermining the

${ }^{6}$ These arguments parallel in some respects those of Nelson and Bridges (1999), who show how firms treated "market forces" as an environmental factor that could be responded to selectively in order to produce a desired gender structure in corporate compensation. Useem (1993) describes how top management often maintained considerable influence over directors even in the face of rising shareholder activism during the ascendancy of the shareholder value movement. 
American Journal of Sociology

incentive to perform), (e) the timing of stock option grants just preceding favorable corporate news, and $(f)$ the backdating of options to correspond with market dips in the company's stock (Yermack 1997; Brenner, Sundaram, and Yermack 2000; Bertrand and Mullainathan 2001; Bebchuk et al. 2002; Bebchuk and Fried 2004; Bebchuk, Grinstein, and Peyer 2006; Kuhnen and Zwiebel 2007).

The second form of evidence for managerial power theory is the firmlevel relationship between managerial power and executive compensation. Gompers, Ishii, and Metrick (2003) argued that the rules of governance that define "power sharing" between shareholders and boards vary across firms, with some resembling "democracies" and others "dictatorships," and that much of the variation in governance evolved in the 1980s as strategies to limit the impact of investor activism. ${ }^{7}$ Several empirical studies have shown that high managerial power and weak governance structures are correlated with higher levels of CEO compensation (Core, Holthausen, and Larcker 1999; Bebchuk et al. 2002; Ang and Nagel 2006; Armstrong, Ittner, and Larcker 2008; Gabaix and Landier 2008). ${ }^{8}$

Proponents of the pay for performance model argue, in opposition to managerial power theory, that variations in pay and changes in pay over time are a market-driven consequence of "superstar" labor markets (Jensen and Murphy 1990; Hall and Liebman 1998; Himmelberg and Hubbard 2000; Murphy and Zábojník 2004a; Gabaix and Landier 2008). Gabaix and Landier's model is illustrative. They argue that CEO talent is worth more in larger firms, and this presumption provides an incentive for firms to hire and pay so that CEO talent and firm size become positively correlated. Under the assumption that talent and firm size were distributed according to a power law, their model produces highly skewed payments to CEOs at the largest firms. At the same time, their model produces an efficient sorting of talent across companies with corresponding gains in both profit to firms and compensation to executives even as it produces "composite rents" that are shared between corporations and executives. The empirical demonstration in this literature that pay, performance, and firm size are statistically related is interpreted as evidence that typical

\footnotetext{
${ }^{7}$ Gompers et al. found that the "democracy" portfolio outperformed the "dictatorship" portfolio by $8.5 \%$ per year. Bebchuk, Cohen, and Ferrell (2005) found that six of the provisions monitored by the Investment Responsibility Research Center-staggered boards, limits to shareholder amendments of the bylaws, supermajority requirements for mergers and for charter amendments, poison pills, and golden parachute arrangements-account for most of the relationship between governance and stockholder returns.

${ }^{8}$ Gabaix and Landier (2008), e.g., found that a 2-SD drop in the quality of corporate governance was associated with an $11.4 \%$ increase in CEO compensation. They noted that this effect was "small compared to the dramatic increase in pay" (p. 70).
} 
supply and demand factors are working in the executive labor market, just as they work in typical labor markets.

For those focused on trends in income inequality, the most salient aspect of executive compensation is not the variation in pay across companies, but rather the upward "ratcheting" of executive compensation, that is, the fact that executive compensation rose throughout the 1980s and 1990s at a faster pace than average wages, average managerial wages, or even corporate earnings. Ang and Nagel (2006) operationalized ratcheting as when CEOs are paid more in year $t$ than one would predict on the basis of the pay for performance model for the prior year. They found that the proportion of CEOs getting higher than predicted compensation rose from $53 \%$ in the 1970 s to $57 \%$ in the 1980 s and 1990s, which-they arguedleads to a persistent rise in mean and median compensation. ${ }^{9}$ This upward ratcheting coincided with the tendency for corporations to provide a larger share of executive pay in equity-based incentive schemes, which was justified as a closer alignment of the interests of managers and stockholders (Useem 1993).

Proponents of managerial power theory view the pattern of upward ratcheting of executive compensation as evidence of increasing rent extraction by executives from poorly governed corporations. Advocates of the pay for performance model, however, counter that managerial power theory does a poor job of accounting for the upward trend in CEO compensation. For example, Murphy and Zábojník (2004a) wrote that "the Bebchuk et al hypothesis does not provide a satisfactory reason for the increase [emphasis theirs] in CEO pay. Surely, CEOs were trying to extract rents even 30 years ago. But then, one would have to argue that over time the boards of directors became more and more captive. However, if anything, the opposite appears to be true" (p. 192). Several other studies report that corporate governance was becoming more effective in the 1990s even as salaries were ratcheting upward (Holmstrom and Kaplan 2001; Bebchuk and Fried 2004; Hermalin 2005). Additionally, some studies fail to find evidence that poor governance is linked to upward ratch-

${ }^{9}$ Nagel (2007) further finds an inflation-adjusted increase of at least $5.5 \%$ per year in median Standard and Poor's (S\&P) pay in the early 1980s after taking performance into account and finds that much of this increase stems from the increased use of pay surveys and the corresponding rise in pay of CEOs who were paid less than similarly performing peer CEOs. According to Nagel, the percentage of those who are "persistently underpaid" drops from $39 \%$ in the 1970 s to $32 \%$ in the 1980 s. He also finds that the percentage of persistently underpaid CEOs further decreased in the 1990s after line-item CEO pay was disclosed starting in 1992, as did the percentage of persistently overpaid CEOs, which he attributes to improvements in governance. Bizjak, Lemmon, and Naveen (2007) also found that CEOs who were below the median of their natural benchmark population received larger raises in compensation over the 1992-2005 period of time. 


\section{American Journal of Sociology}

eting of executive compensation (Bizjak et al. 2007; Gabaix and Landier 2008). ${ }^{10}$

Defenders of the pay for performance model argue instead for a market explanation for rising executive compensation. Gabaix and Landier (2008), for example, argue that the marginal value of a CEO's talent increases with the value of the firm under his control and that this proposed relationship leads to an "efficient" bidding up of CEO compensation as firm size goes up in order to achieve the optimal sorting of CEO talent and firm size. Gabaix and Landier claimed to find-in contrast to Bebchuk and Grinstein (2005) - that all of the increase in CEO pay since 1992 could be explained by optimal sorting in the presence of observed increases in firm size. ${ }^{11}$ This argument, however, was challenged as unpersuasive by proponents of the managerial power model. Nagel (2008) replicated their study with a revised sample and-like Bebchuk and Grinstein (2005)—found that firm size explains only $50 \%$ of the increase in compensation. In addition to this problem, the Gabaix and Landier explanation relies on strong assumptions about the interactive effect of talent and firm size on performance and about the functional form of the unobserved distribution of talent in the population of executives and wouldbe executives. ${ }^{12}$

${ }^{10}$ Bizjak et al. (2007) found no evidence that pay increases to CEOs ranked below the median of their peer groups were linked to standard measures of poor governance. Gabaix and Landier (2008) tested the governance failure theory by testing for whether compensation returns for being the executive of a poorly governed firm rise with stock market performance, and the test failed, which they interpreted as evidence against the idea that "skimming" produces ratcheting. Other scholars argue more neutrally that upward ratcheting was an information problem; boards failed to accurately estimate the true cost of stock options to the firm (Hall and Murphy 2003).

${ }^{11}$ Other arguments include that CEOs were previously paid too low and there is a one-time catch-up that occurred (Jensen and Murphy 1990); that market booms increase the demand for CEO talent and produce an increase in pay (Himmelberg and Hubbard 2000); that "general managerial skill" as opposed to firm-specific skill has become more valuable, which has produced increased competition by firms for external CEOs (Murphy and Zábojník 2004a); that the higher risk of firing due to strengthened corporate governance produced higher compensation to offset the risk (Hermalin 2005); and that it is too costly for firms to index CEO contracts so that they do not reward "luck" (Oyer 2004). Murphy (2002) and Hall and Murphy (2003) attribute the rise in stock options not so much to managerial power as to board ignorance about how much the options are worth.

${ }^{12}$ Gabaix and Landier provide an equilibrium result that shows how equilibrium salaries change as a function of the fraction of firms that propose to provide increased compensation to their CEOs, and they report that if $10 \%$ of firms want to double compensation, this will lead to a doubling of all CEO compensation in equilibrium. However, their formula implies implausibly high equilibrium pay levels as the proportion of firms that decide to double CEO compensation rises to $50 \%$ (own calculations). 
Much of the empirical evidence put forward to support either the managerial power or the pay for performance theory searches for statistical patterns between firm-level, industry-level, and executive-level characteristics on the one hand and compensation on the other. Economic sociology, in contrast, favors explanations that focus either on the interaction between local governance and the broader governance environment or on the impact of network ties on economic outcomes. The market governance literature addresses how the national environment responds to political and cultural, as well as functional, imperatives and how local governance involves "strategic efforts at conformity" in order to produce favorable evaluations from institutional third parties and correspondingly higher share prices and business opportunities (Davis 2005; Fligstein and Dauter 2007). ${ }^{13}$ The network literature argues that specific ties among market participants create a pattern of information flow within subnetworks that affects transactions and prices (Baker 1984; Burt 1992; Mizruchi and Stearns 2001). Specific ties among market participants also directly enhance or diminish the status of these participants and thereby affect their perceived quality and their price and cost structure (Podolny 2005). The pay for performance model is admittedly also relational in the sense that all economic models are relational; that is, pay setters look at both local performance and competitive pressures from the market when deciding how much compensation to offer their employees. We see three important questions that need to be addressed in order to establish the differences in these approaches. First, what part of the market does the firm's compensation committee look at when it sets pay; that is, what is the network structure and the content of the network ties between executives and the environment that are implied by pay comparisons? Second, how controlling are these comparisons on pay determination? Third, how does pay setting in response (or not) to these comparisons propagate through the comparison networks that are set up by the compensation process?

\section{COMPENSATION BENCHMARKING}

When rates of external hiring of executives were low, social scientists debated whether executives were paid on the basis of comparisons to the

\footnotetext{
${ }^{13}$ Examples of symbolic and strategic action, which traces back to the work of Meyer and Rowan (1977), include stock repurchase plans (Westphal and Zajac 2001), longterm incentive compensation (Westphal and Zajac 1994, 1998), use of consultants and peer groups to justify executive compensation (Porac, Wade, and Pollock 1999), and discretionary reliance alternatively on market or accounting returns as justifications for executive pay (Wade, Porac, and Pollock 1997).
} 
American Journal of Sociology

"external" labor market or the "internal" labor market (Roberts 1956; Simon 1957), even as earlier empirical studies suggested that executive pay was determined by a combination of these forces (Patton 1951). Certainly by the late 1970s, however, the setting of executive pay often involved institutionalized comparisons between the company's own executive compensation practices and those of "a list of companies comparable to [the compensation director's] organization" (Cook 1981, p. 39). As the practice of recruiting external CEOs became more prevalent and developed its own set of institutions (Khurana 2002; Murphy and Zábojník 2004b), so did the explicit use of benchmarking and labor market analysis as the normatively prescribed model for setting executive compensation.

The benchmarking process is well described in contemporary compensation manuals produced by compensation consultants (e.g., Reda, Reifler, and Thatcher 2008). Some parts of this "standard model" have been incorporated into regulatory practices monitored by regulatory agencies, and company adherence at least to the formal characteristics of this process has been well documented..$^{14}$ The first step is for compensation committees to assess current pay (often, actual pay is not immediately obvious, given the complexities of executive compensation). The next step is a labor market analysis. As one compensation manual describes, "Compensation committees are constantly examining whether the compensation levels of the top executives are reasonable and adequate. This is done for two reasons. First is to ensure that the pay levels are competitive, because if they are not (otherwise referred to as 'below market') another company may try to 'raid the executive talent pool.' Second is to ensure that the compensation levels are neither too high nor too disproportionate (i.e., that there is reasonable balance between salary, annual bonus, long-term incentives, pension, and so on)" (Reda et al. 2008, p. 24). To accomplish this process, compensation consultants are called in and a peer group for the company's executives is identified. New compensation is determined relative to the compensation of the executives in the peer group via negotiations with the CEO.

A number of studies of executive compensation have documented the widespread use of peer groups in the process of setting executive compensation (Porac et al. 1999; Bizjak et al. 2007; Faulkender and Yang 2010), but the interpretation of this practice varies widely. Holmstrom

\footnotetext{
${ }^{14}$ Crystal (1991) found extensive evidence for the use of benchmarking in the 1980s. More recently, Bizjak et al. (2007) found that 96 of 100 S\&P 500 firms that were sampled in 1997 asserted that they used peer groups in their proxies. Ang and Nagel (2006) found the same percentage in their S\&P 500 sample. Whether compensation committees actually consistently behave in ways that compensation consultants recommend is, of course, an open question, and one whose answer might be different under the current regulatory environment than it was in the 1990s.
} 
and Kaplan recently wrote that "prices, including wages, are ultimately set by supply and demand, and benchmarking is nothing more than looking at market prices" (2003, p. 19). They went on to argue that "the main problem with executive pay levels is not the overall level, but the extreme skew in the awards . . . To deal with this problem, we need more effective benchmarking, not less of it." Bizjak et al. (2007) similarly concluded that the practice of benchmarking against peers is used by corporations to retain CEOs by determining their reservation wage. Faulkender and Yang (2010), in contrast, found that firms tend to favor peer groups where the CEO was more highly paid and will forgo including lower-paid CEOs in the same industry in favor of higher-paid CEOs outside of the industry.

Clearly, differing outcomes in the peer group selection process can imply different applications of network principles in the construction of these networks. The perspective of Holmstrom and Kaplan implies that compensation networks are constructed such that individuals in the peer group are equivalently situated with respect to a labor market. At the same time, the research of Faulkender and Yang (2010) implies that the CEOs included in the peer group are not a simple random sample of the firms that would be included on the basis of a reasonable definition of the labor market. This suggests that "labor market comparability" is not an adequate explanation for how peer groups are selected.

The favoring of more highly paid CEOs calls to mind Gould's (2002) and Podolny's (2005) conceptions of network ties as bases for the accretion of status, which gives actors an incentive to create ties with the higheststatus individuals in order to gain status themselves. However, their models posit a mechanism that limits this status-seeking process, namely, the need for ties to be reciprocal. Efforts to form ties with higher-status actors in their models are often not reciprocated either because of time constraints on the potential number of ties that one can reciprocate (in Gould's model) or to avoid the degradation of one's own status that comes from associating with lower-status actors (in Podolny's model).

Compensation networks differ from Gould's or Podolny's networks in the important respect of being cognitive, not social, networks, where ties need not be reciprocated (Kilduff and Krackhardt 1994). To include a particular CEO in one's peer group is to make a rhetorical assertion that the claimed peer is part of the relevant labor market. The motives for the asserted ties are similar (the desire to express comparability with a highly compensated alter is similar to the desire to be accepted as having business ties with a high-status firm in Podolny's model). However, the mechanism by which the asserted peer group tie becomes "real" occurs not through its being reciprocated, but rather when it is accepted by the board and used in the setting of pay. It is, of course, quite possible that 
American Journal of Sociology

assertion and acceptance of these cognitive networks are influenced by actual social ties, that is, business ties among firms as well as social ties among executives and board members within and across firms. The process may also be influenced by whether the peer group membership is easily discoverable by shareholders and interested third parties. Until recent years, the level of transparency was low, but this has gradually changed as firms slowly move into compliance with the 2006 Securities and Exchange Commission (SEC) requirements that peer groups be named in the corporation's yearly proxy report if the company used benchmarking to set executive pay.

\section{MECHANISMS LINKING COMPENSATION BENCHMARKING TO SECULAR RISES IN PAY}

Defenders of CEO compensation levels argue that CEOs do not extract rent because they are being compensated at their reservation wage, which is set by an open and functioning market for executive talent. The economic sociology emphasis on the interface between the institutional environment and firm-level actions provides an alternative basis for concluding that rent capture can occur even in the presence of firm-level competition for CEO talent because rent capture by one CEO produces a higher benchmark that other CEOs can point to as the "market" price. Defenders of CEO compensation levels typically treat governance failure as a firm-level rather than an environmental issue ("Despite its alleged flaws, the U.S. corporate governance system has performed very well" [Holmstrom and Kaplan 2003, p. 20]) and argue that the evidence supports labor market pressure rather than governance as an explanation for executive salaries. The environmental perspective, however, questions this logic as fundamentally flawed to the extent that the failure of governance at one firm can then influence the competition at other firms through the selection of the overcompensated CEO as a peer. The influence is magnified if the overcompensated CEO is more likely to be selected as a peer precisely because his compensation is high. The feedback in this process, moreover, has the potential to generate ratcheting to the extent that firmlevel governance failures continue to occur even sporadically.

Existing studies of ratcheting processes focus on changes over time in the median or in the likelihood that below-median CEOs will have larger than average increases (Ang and Nagel 2006; Nagel 2007, 2008). In contrast, our study examines how a relatively small fraction of above-normative jumps to the right tail of the benchmark distribution, which we describe as "leapfrogging," could affect the evolution of the entire distribution of executive compensation over time. For scholars such as Holm- 
strom and Kaplan (2003), leapfrogging (at least if it is "excessive") becomes a problem of "excessive skew" and an illustration of governance failure in a small number of firms within a system of governance that works well because it identifies the appropriate "market wage" for the great majority of CEOs. This view is inadequate because the benchmarking system contains feedback loops that transform governance problems in some firms into a market reality for others. In this section, we discuss a set of mechanisms that potentially can link benchmarking to secular trends in corporate executive compensation, and then we explore how relatively low rates of leapfrogging can influence the evolution of the distribution of CEO compensation over time. We do not argue that leapfrogging is the only mechanism by which upward ratcheting of pay could occur. Indeed, we expect that managerial power can and would be expressed through other mechanisms, including the control of information about the value of equity and other incentive components of executive compensation (Sorensen 2000; Hall and Murphy 2003) and the mechanism involving below-median pay examined by Ang and Nagel. ${ }^{15}$ We do argue, however, that leapfrogging is a powerful mechanism for ratcheting pay because it allows individual expressions of managerial power at some firms to change benchmarks and thereby affect the pay of CEOs throughout the corporate world.

Our starting point rests on two presumptions. The first is that there is a "natural" group of companies that are "peers" of any given company for purposes of setting compensation, but at the same time, there are ambiguities in the actual identification of these peers that allows for the latitude of discretion. These commonsense but ambiguous criteria can be seen in the wording of compensation guidelines: "Peer companies generally are selected based on similarities to the subject company in terms of revenues, market capitalization and/or industry, oftentimes using Standard Industrial Classification (SIC) codes that are the same as or similar to the subject company ... [such that they are] representative of an appropriate 'market" (Reda et al. 2008, p. 25). ${ }^{16}$ The second presumption

${ }^{15}$ Shifts in accounting and tax policies as well as the growing dominance of the shareholder value paradigm may have contributed to the increased weight of equity compensation in the typical executive compensation package. Patton (1951) argued that the high marginal tax rates of the late 1940s caused companies to limit the ratio of equity to cash compensation so that their executives would be able to use their cash in order to pay the taxes on their equity compensation. More recently, Internal Revenue Service and accounting regulations concerning the implications of equity compensation for corporate profitability created incentives for corporations to use equity-based pay for their top executives.

${ }^{16}$ Data from Faulkender and Yang (2010) showed that industry and size are standard criteria for inclusion in peer groups. Other studies have also established the normative use of industry and firm size as the principal basis for defining peers. 
American Journal of Sociology

is that the complexities of executive compensation make the process of locating the compensation of the focal executive within this distribution less than transparent. Ambiguities in the selection of peer groups and in the placement of executives within the benchmark distribution create multiple opportunities to enhance the compensation of the focal executive. One mechanism could be termed biased sampling from peer group populations. Even if an appropriate peer group population was identified, selections from this population might be nonrandom and produce a higher peer group compensation distribution. A second and related mechanism is the use of what we term "aspiration peer groups" instead of comparable peer groups. Aspiration peer groups are drawn from populations of firms that are bigger than the target firm (and therefore typically have more highly compensated CEOs) on the grounds that the current CEO has the talent to increase his current employer to the size of the aspiration companies. Aspiration peer groups will generally consist of highly paid peers, and CEOs have an obvious incentive to claim as highly paid a group of "peers" as possible up to the limits of what can be justified as a plausible comparison group ${ }^{17} \mathrm{~A}$ third mechanism is the use of ambitious escalators to update the available lagged data about compensation of peer group executives when computing appropriate pay for the focal executive. A fourth mechanism, which is described in the work of Ang and Nagel (Ang and Nagel 2006; Nagel 2007), concerns relatively large increases in pay to CEOs who are below the median of their benchmark distributions. A fifth mechanism, which is the topic of our empirical focus, is the benchmarking of a relatively small fraction of executives to points in the compensation distribution that are higher than normative.

Analyses of firm proxy statements demonstrate that corporations live in a "Lake Wobegon" world where no one should be below average and many are above average. Crystal (1991) found that $35 \%$ of surveyed firms aimed to pay at the 75 th percentile and $65 \%$ aimed at the 50th percentile. Bizjak et al. (2007) found that $73 \%$ of firms in their sample of $100 \mathrm{~S} \& \mathrm{P}$ 500 firms in 1997 targeted the mean or the median of the distribution, whereas most of the remaining firms did not mention their percentile target in their proxy statements. Ang and Nagel (2006) found that between $46 \%$ and $66 \%$ of firms in the S\&P 100 targeted their CEO compensation at above the median of the peer group. Using a sample of S\&P 500 companies for 2005 and 2006, Faulkender and Yang (2010) produced evidence in the cross section that the particular selection of peers-in particular, the 50th and 75th percentiles of compensation within the peer group-has a statistically significant effect on focal CEO compensation,

${ }^{17}$ Han (1994) writes about the process of status seeking through aspirational group membership in the context of choice of auditing firm by American corporations. 
net of standard pay and performance variables. Their finding implies that the upper end of the benchmark distribution indeed affects pay in the cross section. Faulkender and Yang also found that peer groups tend to be somewhat larger firms than the focal firm, that potential firms from the same industry that were excluded from the peer group tend to have relatively low CEO compensation, and that "peer" CEOs from outside the industry tend to have relatively high CEO compensation. Their findings are consistent with the managerial power model of compensation setting. In other words, corporations appear to use both biased sampling and aspiration peer groups in order to justify higher executive compensation. ${ }^{18}$

If peer groups were stable over time and if all firms benchmarked to the 55th percentile, then pay within peer groups would rise such that all low-paid CEOs were paid at the 55th percentile, and thereafter, the distribution would remain stable. Increased pay from one year to the next would be generated by the escalator that firms used to update the lagged benchmark pay when determining pay for this year. However, this model is incomplete because it gives no guidance for CEOs whose pay was already above the 55th percentile of their peer group. Pay increases in this simple model for already highly paid CEOs depend only on the escalator and whatever other performance measures that are used to justify relatively high compensation relative to peers, however they were selected.

Suppose instead that peer groups were stable and that everyone was paid to the 55th percentile in the peer distribution except for a small fraction of above-median CEOs who leapfrogged to the right tail. This leapfrogging would create right skew but would not affect the pay point for firms below the 55th percentile. If, however, enough firms leapfrog from the bottom $55 \%$ of the distribution, they shift the pay point to the right; one must now count up to higher-paid CEOs to reach the new 55th percentile. The increase in pay from one year to the next becomes the sum of the escalator plus the difference between the new pay point and the old pay point.

This second thought experiment is also limited because it presumes stable peer groups. In reality, peer groups are not stable. Even the "natural" peer groups (as defined by firm size and industry) would not remain the same over time given that the relative market cap (and in some cases even industry) of firms will change over time. Along with the potentially very powerful force of temporally variable strategic selection of peers based on CEO compensation (Faulkender and Yang 2010), firm

${ }^{18}$ Faulkender and Yang (2010) also find limited, though not definitive, evidence that these procedures are more common at poorly governed firms. 
American Journal of Sociology

mobility across the space that defines natural peer groups magnifies the possibility that the destination compensation of leapfrogs will directly affect the pay point of benchmark distributions for other firms. In such a situation, leapfrogging creates a ratcheting effect that drives the distribution of CEO pay to the right.

There is an important distinction between superstar "tournament" models of compensation (Rosenbaum 1979; Rosen 1981), which have also been described as "winner take all" markets (Frank and Cook 1995), and benchmarking models of compensation, which have more the character of environment-level cumulative advantage models (DiPrete and Eirich 2006), and therefore are better described as "winners spread the wealth" models. A winner take all model is one in which the rewards at the top of the distribution are far above the average and there is no feedback between rewards at the median and rewards in the right tail. The superstar model provides a static justification for very high pay for superstars, or, in our context, CEOs. A winner spread the wealth model is one that contains a feedback mechanism, which in the case of benchmarking works through social comparison. A model in which top executives were paid a fixed percentage of the company's revenue would produce a highvariance, right-skewed distribution of compensation with no feedback. In effect, this would be a "tournament" model in which the executives who won the slots at the head of the biggest companies were the big winners even among the class of winners who head public corporations. A model in which pay was set relative to the pay of others has the potential to produce escalating pay for everyone, whenever poor governance or even luck raises the pay of a fraction of executives who then function as compensation reference points for other executives. A model in which pay is set relative to the pay of others implies that market governance is inherently a systemwide as well as a firm-level phenomenon. Systemwide governance failure can occur when pay at both "well-governed" and "poorly governed" firms rises on the basis of a combination of a potentially small number of questionably large pay increases that feed back through the benchmarking system. The next sections of this paper describe our data and methods and present estimates of the potential cumulative magnitude of these feedback effects over time.

\section{DATA AND DESCRIPTIVE STATISTICS}

We analyzed information obtained from the S\&P ExecuComp database, which provides information about executive compensation and firm performance for firms in the S\&P 500, S\&P Mid-Cap 400, and S\&P SmallCap 600 indices at some point since 1992. These data, which are described 
in detail on the S\&P website (http://umi.compustat.com), contain information about total yearly compensation for the five highest-paid executives in the firm each year, including salary, bonus, stock option grants, and grants of stock. Basic demographic information is also available including age and gender and date of hire and of separation if applicable. The starting and ending dates of tenure as CEO are available for CEOs, and mobility among corporations can be tracked because the names of each executive are contained in the data. The ExecuComp database contains several important company characteristics including industry, sales, assets, number of employees, revenues, return on assets, return on equity, net income, stock price, and yearly return to shareholders (including dividends). We limited the sample to current CEOs for the analyses reported in this article.

First we provide descriptive information about the change in the distribution of compensation and about compensation mobility of individual CEOs, and then we present results from counterfactual simulations that estimate the impact of leapfrogging on mean and median changes in executive compensation over time.

Figure 1 shows the tremendous rate of increase in mean total compensation for CEOs in the ExecuComp data, and figure 2 shows the observed mean and median change in salary plus bonus (salary/bonus). Adjusted for inflation, the median salary/bonus increased from 1993 through 2005 by $40 \%$, whereas the mean increased by $58 \%$. Adjusted for inflation, the median total compensation went from $\$ 1.6$ million to $\$ 3.2$ million, a $106 \%$ increase, whereas the mean increased by $116 \%$. In 2006, the typical salary/ bonus package dropped considerably in the ExecuComp data, but the total compensation rose to a mean of $\$ 7.1$ million, a $175 \%$ increase over its value in 1993. In contrast, mean annual compensation in domestic industries in the United States as a whole rose in this period by only $15 \% .^{19}$

This strong upward movement in the overall distribution occurred concurrently with high year-by-year mobility in both the upward and downward direction for individual executives. Table 1 shows the distribution of percentage changes in pay for CEOs during these years. As is evident, movement down as well as up was common. Much of the reason for this high year-to-year mobility was that CEOs typically receive various forms of "incentive" compensation that is not necessarily awarded every year, including stock options and long-term incentive payments. CEO year-toyear mobility is much higher than is typical for American workers. Burkhauser, Holtz-Eakin, and Rhody (1997) report that $75 \%$ of American

${ }^{19}$ Table 622, U.S. Statistical Abstract, 2008 (for year 2005), and table 672, U.S. Statistical Abstract, 1995 (for year 1993). 


\section{American Journal of Sociology}

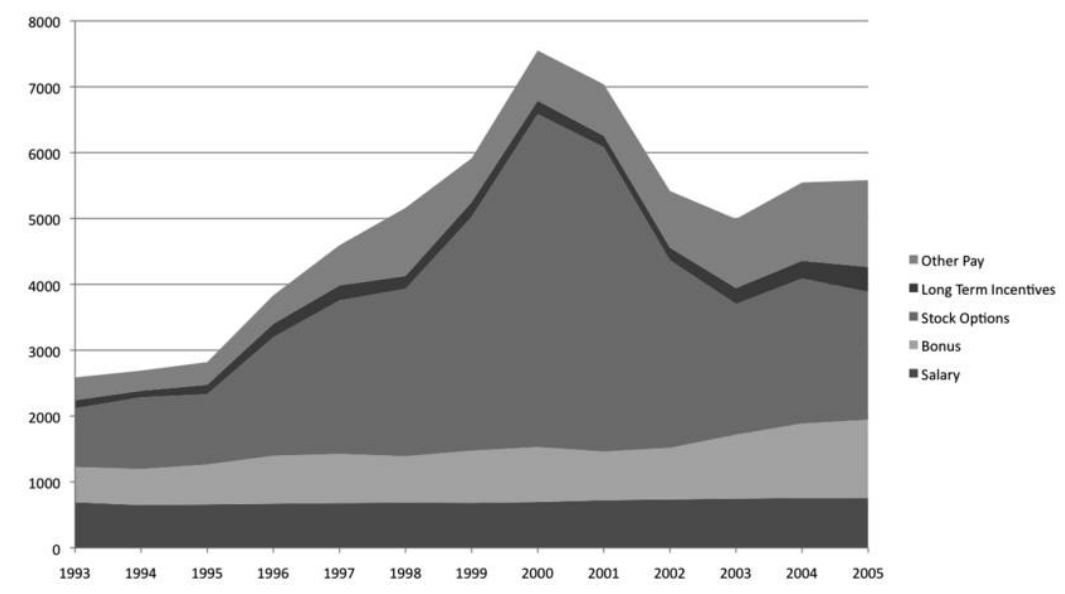

FIG. 1.-Mean CEO compensation, by year (from S\&P ExecuComp data)

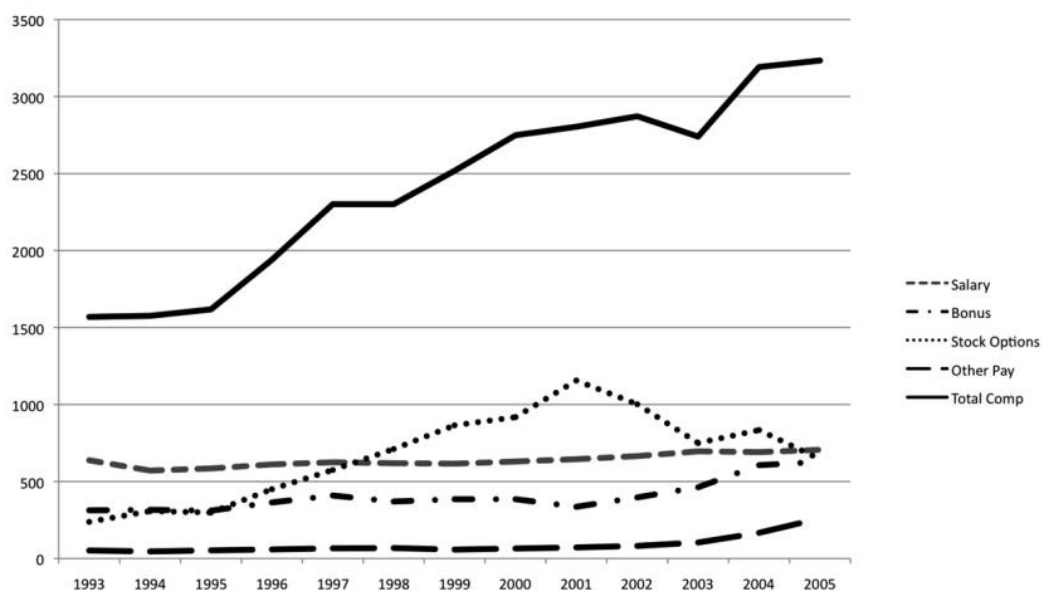

FIG. 2.-Median value of total compensation and major components of CEO total compensation, by year (from S\&P ExecuComp data).

workers in the bottom quintile, between $60 \%$ and $65 \%$ of those in the middle quintiles, and $84 \%$ of those in the top quintile remain in their same quintile of the labor earnings distribution from one year to the next. In contrast, $66 \%$ of CEOs in the bottom quintile, between $42 \%$ and $47 \%$ in the middle quintiles, and $68 \%$ in the top quintile remain in the same quintile the following year with respect to total compensation. Mobility in the salary and bonus component of total compensation is lower but (at $71 \%, 54 \%, 48 \%, 53 \%$, and $75 \%$ immobile in quintiles $1-5$, respectively) 
Compensation Benchmarking

TABLE 1

Percentage of CeOs Who Remain in Their Pay Quintile in Successive Years

\begin{tabular}{|c|c|c|c|c|}
\hline \multirow[b]{2}{*}{ Quintile } & \multicolumn{4}{|c|}{ PAy Component } \\
\hline & Salary & $\begin{array}{c}\text { Salary + } \\
\text { Bonus }\end{array}$ & $\begin{array}{c}\text { Stock } \\
\text { Options }\end{array}$ & $\begin{array}{c}\text { Total } \\
\text { Compensation }\end{array}$ \\
\hline 1 (bottom) ... & 88 & 77 & 45 & 69 \\
\hline $2 \ldots \ldots \ldots \ldots$ & 77 & 52 & 49 & 49 \\
\hline $3 \ldots \ldots \ldots \ldots$ & 74 & 47 & 51 & 44 \\
\hline $4 \quad \ldots \ldots \ldots \ldots$ & 78 & 53 & 46 & 49 \\
\hline 5 (top) $\ldots \ldots$ & 90 & 71 & 59 & 66 \\
\hline
\end{tabular}

TABLE 2

Percentage of Top Quintile Who

WERE IN THE BOTTOM 60\% OF THE

Distribution in the Previous Year

\begin{tabular}{cc}
\hline \hline Compensation Type & Percentage \\
\hline Salary $\ldots \ldots \ldots \ldots \ldots \ldots$ & 1.5 \\
Salary + bonus $\ldots \ldots \ldots$ & 6.8 \\
Stock options .......... & 19.2 \\
Total compensation ... & 13.1 \\
\hline Note. - Date are taken from the ExecuComp \\
database. Sample size (in person-years) is $17,277$.
\end{tabular}

is still higher than for the typical worker. ${ }^{20}$ Table 2 further shows that long-range mobility was also relatively common for CEOs, with considerable mobility from the middle and lower parts of the income distribution to the top quintile within a single year's time.

Figure 3 shows the distribution of the average yearly increase in total compensation and in salary/bonus for the years in which the CEO is present in the data, where values smaller than a $30 \%$ average decline and larger than a $100 \%$ average increase were truncated at these values and only CEOs with at least four years of data are presented. ${ }^{21}$ Clearly, at the individual level, compensation careers were highly variable, though with a positive bias; the median yearly increase in total compensation was $9.7 \%$ and the median yearly increase in salary/bonus was $5.1 \%$. For CEOs

${ }^{20}$ These comparisons understate the difference because they are conditional on the individual being a CEO in consecutive years, and an important source of mobility in the general population is occupational change.

${ }^{21}$ Denote the average increase as $r$ and let $y_{N}$ be the natural logarithm of the last observed compensation, $y_{1}$ be the natural logarithm of the first observed compensation, and $n$ be the number of years in which the CEO was observed. Then $1+r=$ $\exp \left[\left(y_{N}-y_{1}\right) /(n-1)\right]$. 


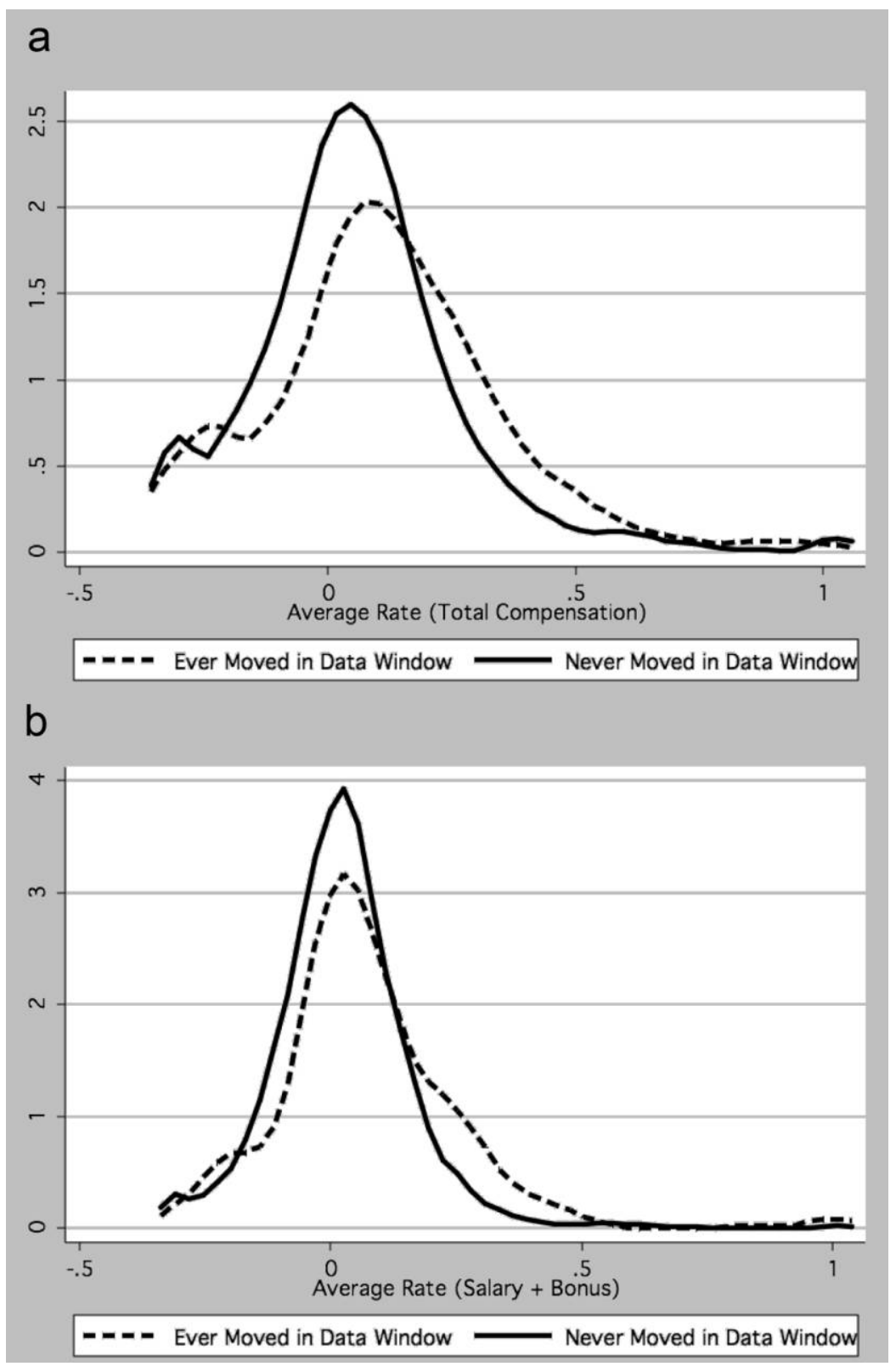

FIG. 3.-Average rate of compensation change for CEOs. $a$, Total compensation. $b$, Salary plus bonus. Notes: $N$ (ever moved) $=317 ; N$ (never moved) $=2,348$. Sample restricted to those who were observed as CEOs in at least four years. $0=$ no increase, 0.5 corresponds to a $50 \%$ increase, 1 corresponds to a $100 \%$ increase, etc. 
who were in the data at least four years, the mean increase from the first through the last year was $6.3 \%$ in mean salary/bonus and $11.5 \%$ in total compensation.

As figure 3 shows, CEO firm changers did better as a group than stayers. According to the ExecuComp data, $11.2 \%$ of the 6,206 individuals who were CEOs of a sample company during our observation period moved to another company, and $14.2 \%$ of all CEO records were those of CEOs who at some point moved from one CEO job to another in the data. CEOs who changed companies had mean average increases in total compensation of $20.7 \%$ and $10.3 \%$ in salary/bonus as compared with $14.0 \%$

for total compensation and $8.9 \%$ in salary/bonus for those who remained with only a single company.

\section{SIMULATING THE EFFECTS OF LEAPFROGGING: METHODS}

\section{Imputing the Peer Groups}

To estimate the impact of leapfrogging on the overall rate of growth of executive compensation, we analyzed compensation trends in the ExecuComp data by means of counterfactual simulations. In the historical data, the peer groups that were actually used by compensation committees are not known (an SEC requirement that peer groups be named was not instituted until 2006, and many firms delayed complying with this requirement for one or more years [Pittinsky and DiPrete 2010]). Instead we have the principles that compensation consultants and companies say they used in choosing peer groups. We used this information to impute peer groups. Because there is more than one way to construct a reasonable operationalization, we used multiple approaches in order to establish the sensitivity of our results to the particular form of the operationalization. Because of evidence from recent data that actual peer group construction is biased toward more highly compensated peers (Faulkender and Yang 2010; Pittinsky and DiPrete 2010), we also operationalize the idea that corporation compensation committees often choose an "aspiration" instead of a comparable peer group for the process of setting executive compensation.

We presume a model of competitive benchmarking against peer groups as described in the compensation literature. In every year, compensation changes are based on a standard procedure. First, current pay is assessed. Then a peer group is identified. A target distribution for the current year is established on the basis of escalating the lagged compensation of executives in the peer group to what is judged to be a reasonable present value. New compensation for the focal CEO is then determined relative 
American Journal of Sociology

to the compensation of CEOs in the peer group via negotiations with the focal CEO.

Our four strategies for imputing peer groups are summarized in table 3. In each case, the coding cut points were chosen in order to assure that a high fraction of peer groups would contain at least 10 firms, which is consistent with guidelines from compensation consultants that peer groups contain about 10-15 executives. Industry priority peer groups were defined as companies in the same two-digit SIC industry category, which was further divided into a top and bottom half on the basis of company market value. Size priority peer groups were defined as companies in the same decile based on market value that were located in the same onedigit SIC industry category. Performance priority peer groups were categorized into four industry sectors crossed with market-value quintiles crossed with return on asset quintiles. These first three definitions are consistent with the norms put forward in the compensation literature about the composition of peer groups. The fourth strategy-aspiration peer groups-defined peer groups as the set of companies that were in the same size priority peer group that the focal company would be in if its market capitalization was one decile higher than actual.

We imputed peer groups under the assumption that ExecuComp firms use other ExecuComp firms as peer groups, because these are the firms for which we have historical data on executive compensation. With its mix of the S\&P Small-Cap 600, the S\&P Mid-Cap 400, and the S\&P 500, the ExecuComp database covers the range of the public corporation population, but it is not a representative sample of this population. Because all S\&P 500 firms are included but only a sample of mid-cap and smallcap firms are included, the ExecuComp firms as a group are larger and more stable than other publicly traded firms. ${ }^{22}$ They also tend to have greater institutional ownership and stronger incentive-oriented pay than non-ExecuComp firms (Cadman et al. 2007). The fact of sampling guarantees that peer groups imputed from the ExecuComp database would not match the actual peer groups even if firms chose their peer groups on the basis of normative principles. We proceed under the assumption that the ExecuComp data provide sufficiently broad coverage to provide valuable insight into how firm-level compensation practices are affecting macrolevel change over time.

At least in theory, the first three definitions of peer groups used in our simulations would produce symmetric peer groups. In other words, every company would be a peer for every other company in its peer group. This would deviate from conventional practice, in which companies would

${ }^{22}$ Together they constitute $22 \%$ of all firms in the Compustat database and $87 \%$ of total domestic market capitalization (Cadman, Klasa, and Matsunga 2007). 
Compensation Benchmarking

TABLE 3

Definitions of Peer Groups

\begin{tabular}{cc}
\hline \hline Peer Group & \multicolumn{1}{c}{ Description } \\
\hline 1. Industry priority & $\begin{array}{c}\text { Two-digit SIC codes define industry groups; each industry } \\
\text { group is divided into two peer groups (top and bottom } \\
\text { half) based on market capitalization } \\
\text { One-digit SIC codes define industry groups; each industry } \\
\text { group is divided into 10 peer groups (deciles) based on } \\
\text { market capitalization }\end{array}$ \\
3. Performance ............ & $\begin{array}{c}\text { Industries are divided into four large groups (agriculture, } \\
\text { mining, and construction; manufacturing and transporta- } \\
\text { tion; wholesale and retail trade; and finance, services, and } \\
\text { administration); each group is divided into quintiles based } \\
\text { on market capitalization, and each market-cap quintile is } \\
\text { divided into quintiles based on return on assets } \\
\text { Peer groups are defined as in size priority; each year, execu- } \\
\text { tives are benchmarked against the companies in the same } \\
\text { industry that are one decile larger in terms of market } \\
\text { capitalization }\end{array}$ \\
\hline
\end{tabular}

sample from the full peer population (not just ExecuComp firms) in order to obtain a peer group of about $10-15$ firms. Our definitions also deviate from our understanding of current (and probably also past) actual practice, in which companies sometimes go outside of the normative peer population when they construct ostensible peer groups (Pittinsky and DiPrete 2010). Because of sampling, companies would not typically have symmetric ties even if their peer group consisted of companies of similar size in the same industry. The inclusion of companies outside the same size/ industry group would - we expect-further increase the extent of asymmetry in peer group ties. Meanwhile, aspiration peer groups are clearly not symmetric. The use of aspiration peer groups implies that the compensation committees of the focal company choose other companies that are larger than themselves as peers, and these companies choose still larger companies as their peers.

As a practical matter, we operationalized the peer groups of at least some of the companies as asymmetric with all four of our operationalizations in order to preclude the use of very small peer groups in our simulations. Reda et al. (2008) argue that peer groups should consist of about 10 or more companies, which is consistent with our own examination of recent data (Pittinsky and DiPrete 2010). In cases in which a company's peer group was smaller than 10 on the basis of each of our formal criteria, we relaxed the operationalization by adopting a hierarchy of strategies (first shifting to quintiles instead of deciles and then successively assigning one of the other peer group operationalizations until the 


\section{American Journal of Sociology}

size threshold was reached). These expansions of the peer group definition, which affected about one in six companies, cause the definitions of peer groups to be asymmetric using any of our four strategies for operationalizing peer groups.

\section{Simulation Procedure}

The first step in our procedure is to simulate the setting of CEO compensation by benchmarking CEOs against their normative (imputed) peer groups in order to recover a trend that approximates what is actually found in the data. We apply this simulation first for total compensation and then again for the combination of salary and bonus, and we did the simulation separately for each of the four imputations of peer groups. We presume that last year's compensation for peer CEOs is observed by the compensation committees and that they update this lagged compensation distribution by a certain amount to bring it to present-day levels. We then presume that compensation committees paid the CEO in each year according to his actual rank in the compensation distribution of his peers. As an important initial step, therefore, we compared the focal CEO's compensation in year $t$ with the updated distribution of compensation in the peer group, and we thereby identified the actual rank of every CEO in his normative peer group. The ranks of CEOs within normative peer groups in each year are empirical facts that are derived from the actual data.

We then use these ranks as key input data in order to simulate pay increases each year and thereby approximate the actual rate of increase of the mean and median of the compensation distribution over time. We call this step our baseline simulation and implement it as follows. From the actual compensation of all CEOs in year $t_{0}$, we computed the updated (and therefore simulated) distribution of compensation in the peer group of each CEO for year $t_{0}+1$ using the yearly escalator. Taking the empirically given percentile of each executive within his peer group each year as key input data, we assigned each CEO the mean of the compensation at the decile lower and the decile higher than his own rank in his peer group for year $t_{0}+1 .^{23}$ After computing the pay for each CEO in year $t_{0}+1$ in this way, we used this set of simulated compensations to

\footnotetext{
${ }^{23}$ We multiplied the compensation at the 10th percentile by a value less than one, and we multiplied the compensation at the 90th percentile by a value greater than one in order to obtain benchmark points for the two tails of the distribution. Along with the escalator, these tail multipliers were chosen in order to track the mean, median, and 75 th percentile of the actual compensation distribution over time. If the focal CEO is ranked below the 10th percentile or above the 90th percentile within his peer group, we set his new compensation at one of these tail values.
} 
obtain the distribution of pay within peer groups for year $t_{0}+2$. We continue this process for each year covered by the ExecuComp data, always using observed ranks in one-year-updated real compensation distributions as key input data. To repeat, the goal of the baseline simulation was to recover a rate of increase in the observed distribution of CEOs that approximates the actual changes in the median, 75th percentile, and mean of the distribution of compensation over time. If peer groups were extremely large, our procedure would - by construction-exactly reproduce the observed compensation distribution in every year. However, because peer groups are typically between 10 and 30 companies in size, the compensation values we obtain through this process are only approximate, and therefore, we recover a reasonable approximation of the changing distribution over time by tweaking the escalators and by tweaking the scale values that are used to set pay below the 10th percentile and above the 90th percentile. ${ }^{24}$

Having produced a baseline simulation that recovers the approximate pattern of compensation change over time via an explicit benchmarking mechanism, we then performed a series of counterfactual simulations to estimate the effect of capping compensation for CEOs who moved to the upper tail of their benchmark distributions. We did this in three ways, each of which was progressively less restrictive, first for total compensation and then for the sum of salary and bonus. We label these three capping procedures as "stringent capping," "performance-based capping," and "tenure- and performance-based capping" and implement them as follows.

1. Stringent capping.-In the most restrictive capping, we limited compensation increases to the 75 th percentile of the escalated peer group compensation distribution for CEOs who were ranked above the 80th percentile of their peer group in year $t+1$ but were placed below the

\footnotetext{
${ }^{24}$ In a simpler set of baseline and counterfactual simulations, we made the assumption that history was smooth, and we therefore used the same values for these parameters each year. Our goal in this simpler simulation was to produce an overall rate of growth in the median, 75th percentile, and mean compensation that approximated the actual growth over our entire time window without the rise and fall surrounding the tech stock crash. Because we obtain similar effects from leapfrogging in both scenarios, we show only the graphs for the historically faithful trend. For simulations that attempted to follow the actual rise, fall, and subsequent rise of compensation, we used the median change in compensation between the lagged and the current year as the peer groupspecific escalator. In effect, we assumed that compensation committees would know how compensation in their local environment was changing in each year and that they would use this information to update the lagged benchmark data. For the smooth compensation change simulations, we instead assumed that every compensation committee increased the lagged compensation data by $3 \%$ in real terms before benchmarking.
} 
American Journal of Sociology

70th percentile of their peer group in year $t$. CEOs who were ranked above the 80th percentile in compensation in the previous year were not capped.

2. Performance-based capping.-The second, less restrictive form of capping allowed leapfrogging based either on CEO performance or on CEO mobility. We used logistic regression to predict the probability of being placed above the 80th percentile in their peer group on the basis of the market value of the company last year, the change in market value of the company between last year and this year, and the change in the average market value of companies in the peer group between last year and this year. We then allowed leapfrogging for CEOs whose probability of being placed above the 80th percentile on the basis of performance was in the top $30 \%$ of all CEOs. In addition, we allow leapfrogging for all CEOs who were CEOs in the lagged year and became CEO of a new company in the current year. Other CEOs were subjected to stringent capping as described above.

3. Tenure- and performance-based capping.-The third, still less restrictive, form of capping was to allow uncapped placement for all individuals who became CEOs of a new company in the current year, regardless of whether they were also CEOs in the lagged year. Other CEOs were subjected to performance-based capping as described above.

For example, imagine a CEO in a company that, on the basis of one of our operationalizations of peer groups, has about 15 peers, and let us take the case of salary plus bonus (abbreviated as "pay") as the compensation component of interest and consider tenure- and performance-based capping. Once the specific set of peers was determined, it became possible to rank this focal CEO in each year with respect to his peer group. Let us suppose that his ranking on pay in years $t_{1}, t_{2}, t_{3}$, and $t_{4}$ was eighth, twelfth, fifteenth, and twelfth, which corresponds to the 50th percentile, the 75 th percentile, the 94 th percentile, and the 75 th percentile. Let us further assume that - on the basis of the logistic regression described above-his probability of being placed above the 80th percentile in his peer group was in the 65th percentile of all predicted probabilities for CEOs in year $t_{3}$. In year $t_{1}$, his pay would not be capped because it was at the 50 th percentile. In year $t_{2}$, his pay was at the 75 th percentile, and so again it would not be capped. If no one else in his peer group (whose membership may have changed between times $t_{0}$ and $t_{1}$ ) was capped in year $t_{1}$, then the focal CEO's pay in year $t_{2}$ would be identical to his pay in the baseline simulation. If, however, other CEOs in the $t_{1}$ peer group had capped compensation according to the rules of tenure- and performance-based capping, it would be possible for the focal CEO's pay in year $t_{2}$ to be affected because the 75 th percentile (strictly speaking, the average of the 70th and 80th percentiles) would be lowered if the com- 
pensation for the CEO at the 80th percentile in the year $t_{1}$ peer group had been capped that year, on the basis of his standing within his peer group as constituted in year $t_{0}$.

Once any particular focal CEO's pay is affected by being benchmarked against another $\mathrm{CEO}$ whose pay has been capped, it then affects the pay of other CEOs who are benchmarked against him. Meanwhile, in year $t_{3}$, our focal CEO ranks at the 94th percentile of his escalated $t_{2}$ peer group. In our example, his performance in year $t_{3}$ was not strong enough to merit being over the 80th percentile, but he is nonetheless not capped in that year because he ranked highly enough in the $t_{2}$ distribution to be exempt from capping. The capping of other CEOs, however, would continue to affect his pay from year to year because it affects the benchmark distribution. If we changed this example only slightly to put our focal $\mathrm{CEO}$ at the 50th percentile in year $t_{2}$, then his inadequate performance as of year $t_{3}$ would result in his $t_{3}$ pay being capped at the 75 th percentile of his benchmark distribution. This capping of his $t_{3}$ pay would not directly affect his $t_{4}$ pay, which is set against the escalated pay of his $t_{3}$ peer group. The capping of his $t_{3}$ pay would, however, affect the pay of other CEOs depending on whether he was in their peer group and depending on their rank relative to his rank in their benchmark distribution in that year. In this manner, the capping of the pay of some CEOs percolates through the system over time. Conversely, if we use the capped pay distribution as the baseline, the effects of leapfrogging are expressed as the growing gap between the pay distribution in the baseline simulation and the pay distribution in the tenure- plus performance-based capping distribution.

In any given year only about $5 \%$ of CEOs were capped by our least strict criterion (see table 4). However, the identities of capped CEOs differ from year to year. We determined that $26 \%$ of CEOs in the ExecuComp distribution would have been capped either in their total compensation or in their salary/bonus compensation at the 75 th percentile of their benchmark distribution at some point in time during the years observable with the ExecuComp data using industry priority peer groups. To rephrase, about a quarter of CEOs were leapfroggers by one or the other of these metrics in some year covered by the ExecuComp data. However, the principal effect of leapfrogging on the compensation distribution occurs via its cumulative effect over time as it affects the compensation of other CEOs through the benchmarking process. Restating this in terms of compensation capping, the cumulative effect of capping occurs because capped CEO compensation affects the distribution of compensation in the benchmark distributions. It is this environmental effect that causes the suppression of leapfrogging to affect compensation of other CEOs in our simulations. Because we use actual ranking within normative peer groups 
American Journal of Sociology

TABLE 4

Number of CeOs Whose Placement Was Capped, Based on Industry Priority PeEr Groups

\begin{tabular}{|c|c|c|c|c|c|}
\hline \multirow[b]{2}{*}{ YEAR } & \multicolumn{3}{|c|}{ MEthod OF CAPPING } & \multirow[b]{2}{*}{ Total } & \multirow{2}{*}{$\begin{array}{l}\text { CEOS CAPPED } \\
\text { UNDER LEAST } \\
\text { STRICT METHOD } \\
(\%)\end{array}$} \\
\hline & Strictest & $\begin{array}{l}\text { Less } \\
\text { Strict }\end{array}$ & $\begin{array}{l}\text { Least } \\
\text { Strict }\end{array}$ & & \\
\hline $1993 \ldots$ & 186 & 29 & 29 & 1,113 & 2.6 \\
\hline $1994 \ldots$ & 172 & 102 & 83 & 1,517 & 5.5 \\
\hline $1995 \ldots$ & 149 & 126 & 99 & 1,565 & 6.3 \\
\hline $1996 \ldots$ & 141 & 110 & 86 & 1,603 & 5.4 \\
\hline $1997 \ldots$ & 136 & 86 & 67 & 1,636 & 4.1 \\
\hline $1998 \ldots$ & 155 & 111 & 87 & 1,641 & 5.3 \\
\hline $1999 \ldots$ & 158 & 108 & 78 & 1,720 & 4.5 \\
\hline $2000 \ldots$ & 153 & 123 & 99 & 1,701 & 5.8 \\
\hline $2001 \ldots$ & 143 & 134 & 94 & 1,597 & 5.9 \\
\hline $2002 \ldots$ & 122 & 108 & 84 & 1,605 & 5.2 \\
\hline $2003 \ldots$ & 128 & 110 & 82 & 1,630 & 5.0 \\
\hline $2004 \ldots$ & 138 & 114 & 95 & 1,629 & 5.8 \\
\hline $2005 \ldots$ & 145 & 122 & 94 & 1,625 & 5.8 \\
\hline
\end{tabular}

as a key input variable, it follows that the capping of any particular CEO's compensation at the 75th percentile of the escalated benchmark distribution would have no direct effect on his future compensation in our simulation. Compensation in our model is not a function of base year compensation, but only of the compensation of peers and one's actual rank in that benchmark distribution as computed each year from the actual compensation data. The cumulative effects come from the spreading impact of capping (alternatively, leapfrogging) on benchmark distributions.

The effect of capping (alternatively, leapfrogging) spreads for several reasons. Most directly, the capping of a fraction of CEOs in the right tail of peer group distributions affects the compensation of other highly ranked CEOs by modifying the right tail of the peer group distribution against which they are benchmarked. The capping will gradually affect lowerranked CEOs as well through the process of change in the constitution of the normative peer group. As the size (i.e., market value or, depending on the specific operationalization, return on assets) of any specific firm changes, it can grow or shrink into a different peer group. This process will change the ranking of CEOs in the benchmark distributions. It will change some CEOs from being relatively low ranked in their peer group in year $t$ to being higher ranked in year $t+1$ because their firms fall into a peer group made up of smaller firms. It will change some other CEOs from being relatively high ranked in their peer groups in year $t$ to being 
lower ranked in year $t+1$ because their firms grow into peer groups made up of larger firms. Furthermore, movements of some firms into larger- or smaller-size classes between years $t$ and $t+1$ will change the rank of the CEOs of other firms that do not change peer groups, because the mobility of some firms changes the group of CEOs that other CEOs are ranked against. This process of reconstitution of peer groups from one year to the next will shift some capped CEOs to lower ranks than the 75th percentile and will therefore affect the compensation of CEOs who were ranked below the right tail of their benchmark distribution. This process of reconstitution causes the curtailing of leapfrogging to gradually spread to other parts of the distribution of peer groups. Meanwhile, because the capping process is occurring within different size classes through the ExecuComp population, the impact of capping appears throughout the population distribution of CEO compensation.

We expect that the feedback effects of capping (equivalently, leapfrogging) would accumulate over time. How rapidly these effects accumulate, of course, depends on the amount of capping. Thus, we expect the effects of capping to be strongest under stringent capping and weakest under tenure- and performance-based capping. The process by which peer groups are formed is also expected to affect the impact of compensation capping on the secular growth in compensation. The fact of leapfrogging can be disguised through the use of aspiration peer groups; the higher paid the asserted peer group, the lower a focal CEO will rank in this peer group for any specific compensation package. Thus, even generous increases in CEO compensation will not necessarily move a focal CEO into the right tail of his benchmark distribution if the CEOs chosen for the asserted peer group are sufficiently highly paid. Finally, because CEO pay and company size are strongly correlated, one can obtain a highly paid peer group by asserting an aspiration peer group of sufficiently large companies.

\section{RESULTS}

As noted above, table 4 shows the number of individuals who were capped at the 75 th percentile of the industry priority peer groups. The right tail of any particular peer group might be in the right tail of the overall distribution. However, it might also be in the middle, or even below the middle of the overall distribution of CEO compensation, depending on how the compensation of the peer group CEOs compared with compensation of CEOs in the broader population. Furthermore, and consistent with figure 3 , the highly dynamic character of executive compensation causes the rank of CEOs in the overall compensation distribution to 
American Journal of Sociology

change from year to year. Figures 4 and 5 show the location of CEOs who were ever capped according to our least strict criterion (tenure- and performance-based capping) within the actual compensation distribution of the ExecuComp CEO population, using industry priority peer groups. In these figures, each CEO is scored by his rank within the population of all CEOs for each year. All CEOs who were never capped were dropped, and all years are dropped from the files of ever-capped CEOs before the first time that compensation is capped. As is evident from these figures, the modal position of ever-capped CEO compensation is near the top of the population distribution, but a significant portion of the mass of this distribution is also found in the second, third, and fourth quintiles.

Leapfrogging has the potential to influence the evolution of the entire distribution of CEO compensation, even though the individual leapfrogging events occur in the right tail of any particular peer group.

The extent of this influence is clarified through an examination of the results of our counterfactual simulations. Figures 6 and 7 show the results for mean total compensation and median total compensation for the four representations of peer groups. The dotted line shows the actual change in total compensation at the mean over time. The smooth line without year markers (labeled "as simulated" in the legend) shows the movement of the simulated compensation distribution, which, by construction, approximates the movement of the mean of the actual distribution. The other three solid lines are the consequences of constraining compensation by controlling leapfrogging as defined above. ${ }^{25}$ Because the ungoverned simulated distribution cannot exactly match the true distribution, one should compare the constrained simulations with the unconstrained simulation in order to assess the impact of capping leapfrog compensation at the 75 th percentile on the overall growth in executive compensation. The specific quantitative features of these different growth curves depend on the assumptions underlying each simulation and would vary if we shifted these assumptions. We focus, therefore, on the qualitative comparisons, which are stable across the various simulations that we have conducted.

Even when we use the least strict tenure- and performance-based capping, we see a considerably slower rate of growth of mean total compensation when we restrict leapfroggers to the 75 th percentile of their benchmark distributions. In each of the four panels, it can be seen that the rate

${ }^{25}$ The bottom line in each graph in figs. 6-9 (diamond marked "capped") corresponds to "stringent capping" as defined in the text. The next-higher line (triangle marked "win/move") corresponds to "performance-based capping." The next-higher line (circle marked "win/move/new") corresponds to "tenure- and performance-based capping." The "actual" line comes from the data, and the "as simulated" line comes from the baseline simulation. 


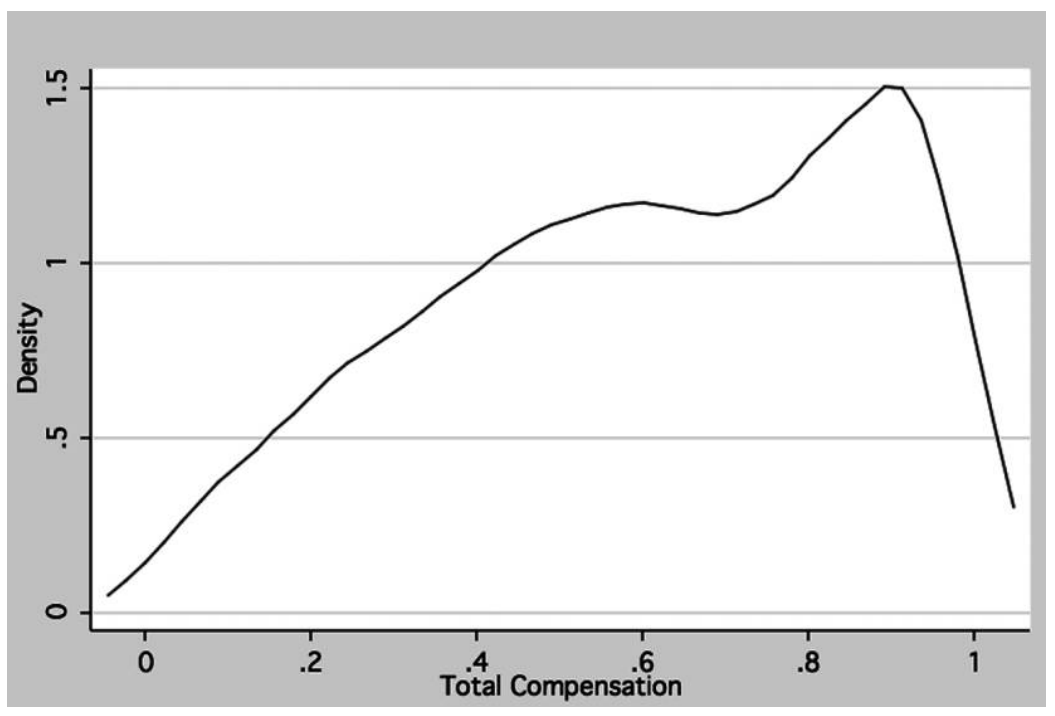

FIG. 4.-Rank of capped CEOs in the overall distribution: year of cap and subsequent years.

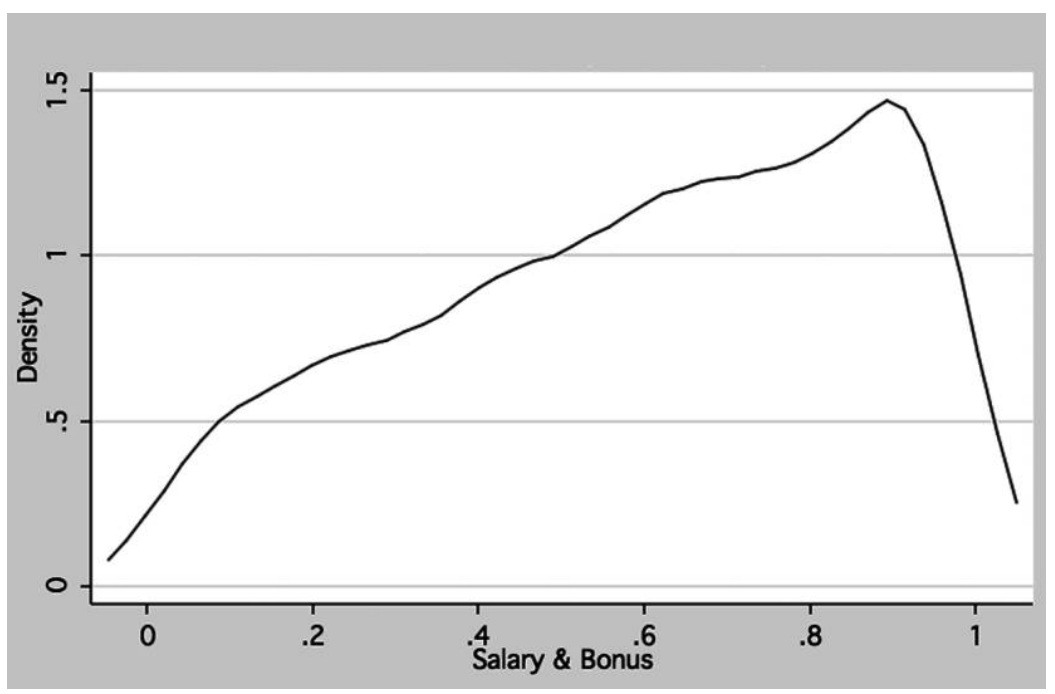

FIG. 5.-Rank of pay-capped CEOs in the overall distribution: distribution over year of cap and subsequent years. 


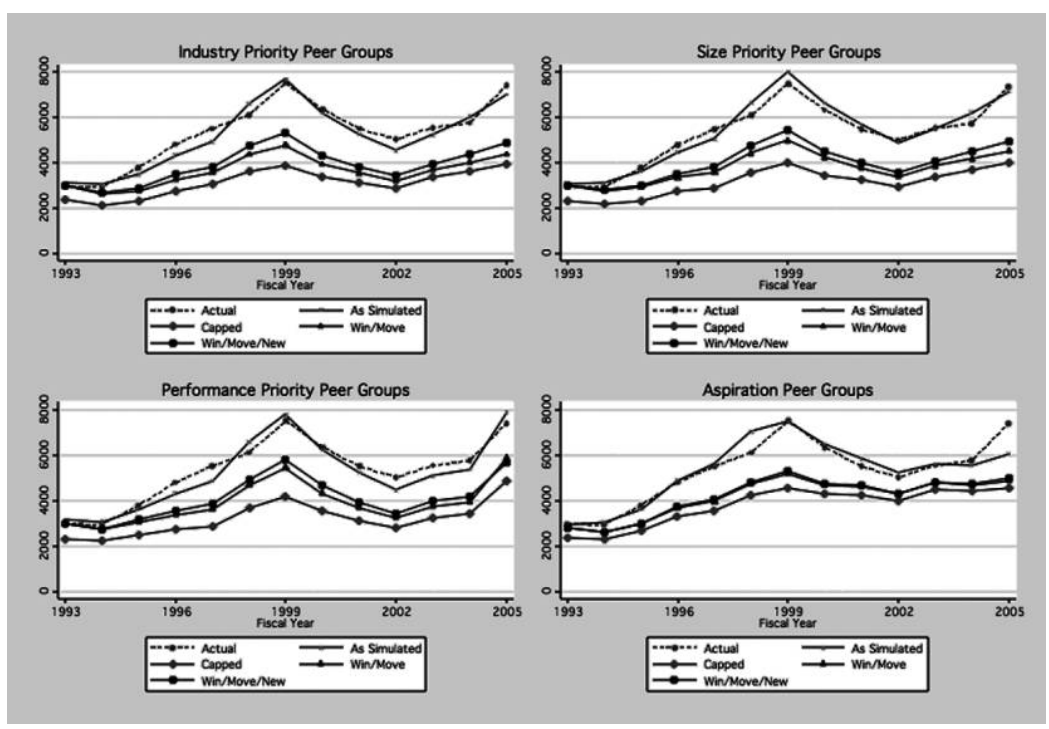

FIG. 6.-Growth of simulated mean total compensation, by year

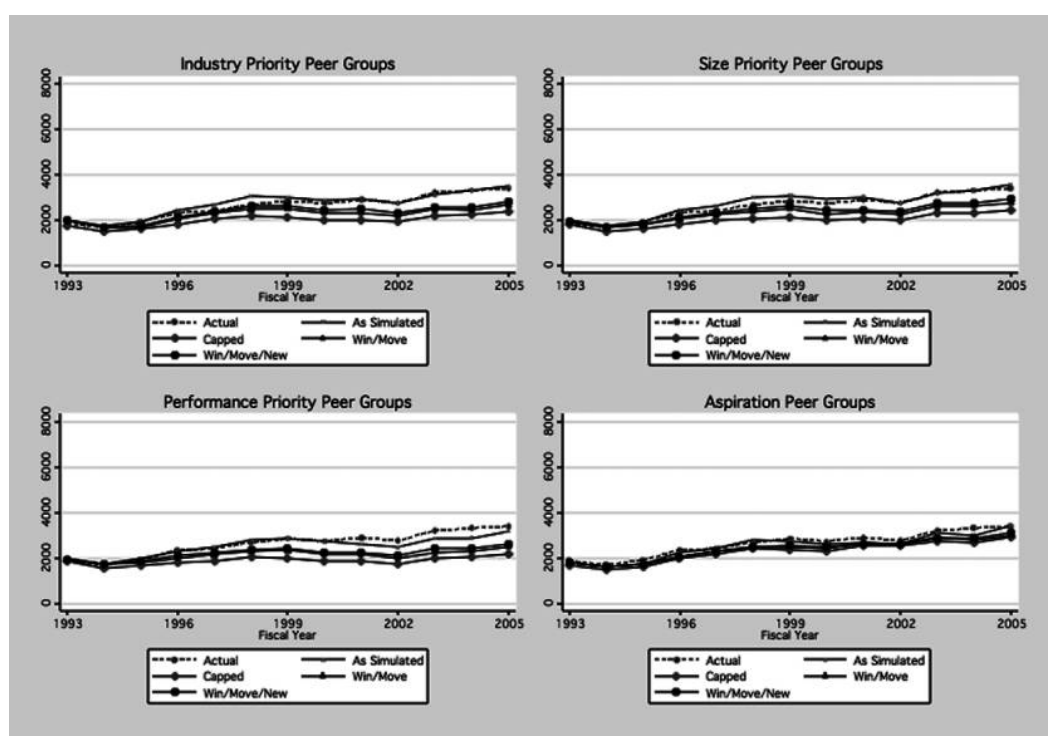

FIG. 7.-Growth of simulated median total compensation, by year 
of increase of mean total compensation would still have been very high during the 13-year period, going from about $\$ 3$ million in real terms in 1993 to nearly $\$ 5$ million by 2005 for industry and size priority peer groups. At the same time, it is apparent in each of the charts that leapfrogging had a considerable effect on change in mean total compensation: up to half of the growth is removed when leapfrogging is controlled. By comparing the size priority aspirations peer groups in the bottom right panel with the size priority peer groups in the top right panel in figure 6 , we see that the effect of capping (and hence the effect of leapfrogging itself) is diminished when aspiration peer groups are used for benchmarking. The reason for this is obvious: the higher the compensation of the benchmark distribution, the lower will be the ranking of the focal CEO in that distribution. The size of his compensation increase depends both on where he is placed in the peer distribution and on how elevated the peer distribution is relative to his own compensation. Clearly, it would be possible to have given almost all capped CEOs the very same compensation that they did in fact receive but keep this compensation below the 80th percentile of a peer distribution if sufficiently highly paid CEOs were chosen as the peers. In our simulation, we used CEOs of companies that were one decile larger in market cap as the way to operationalize aspiration peer groups. With this choice, we see that the capping of compensation jumps continues to have a noticeable effect on the rate of growth of compensation. Had we chosen aspiration groups that were two deciles ahead of the focal company, the effect of capping would no doubt have diminished still further. Of course, placing a CEO in the middle of a distribution of CEOs who are "peers" in name only obscures the jumps but does not eliminate them.

Figure 7 shows growth at the median, which we put on the same scale that was used for total compensation in figure 4. Median compensation is clearly lower than mean compensation, which reflects the strong right skew of total compensation in the ExecuComp database. Of principal interest for our purposes, however, is that growth in median compensation is also slowed by the capping of leapfrogging above the 80th percentile within individual peer group distributions. Compensation practices in the right tail of individual peer groups affect the entire distribution of CEO compensation for companies within the ExecuComp data.

Figures 8 and 9 show similar graphs for trends in the salary/bonus component of total compensation. The salary/bonus component of total compensation is more stable across the careers of individual executives than total compensation is because bonuses are typically earned every year whereas long-term incentive payments were not awarded on a yearly basis by many of the firms in the ExecuComp data. Figure 8 shows that a considerable portion of the long-term gain in mean salary/bonus was 


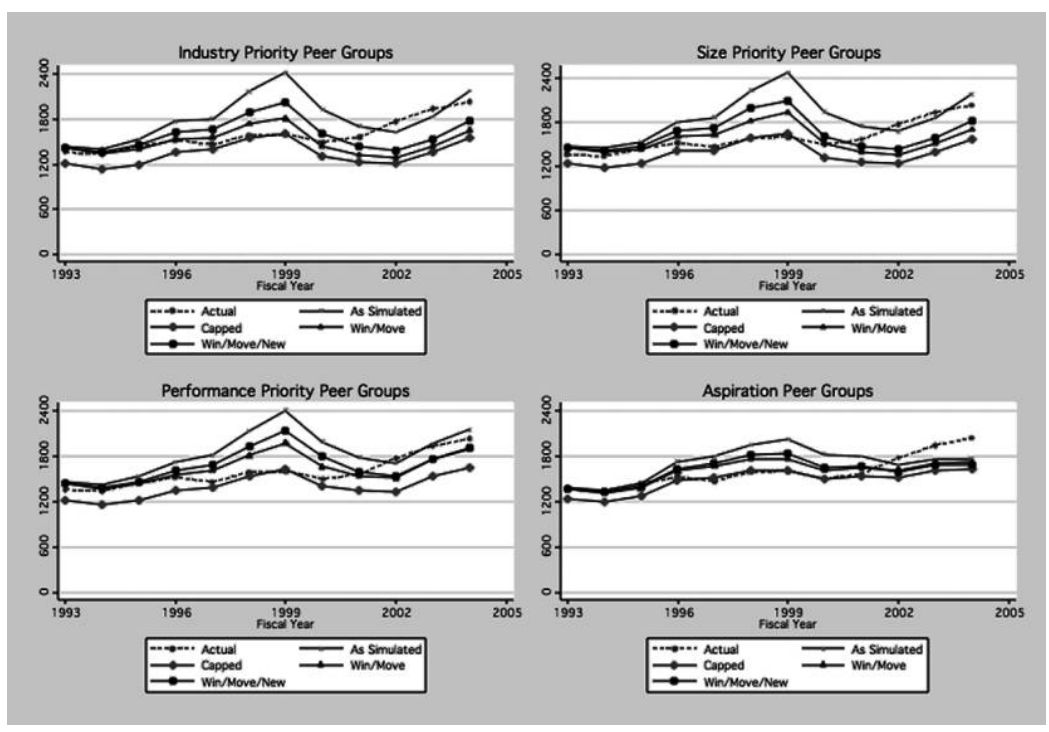

FIG. 8.-Growth of simulated mean salary plus bonus, by year

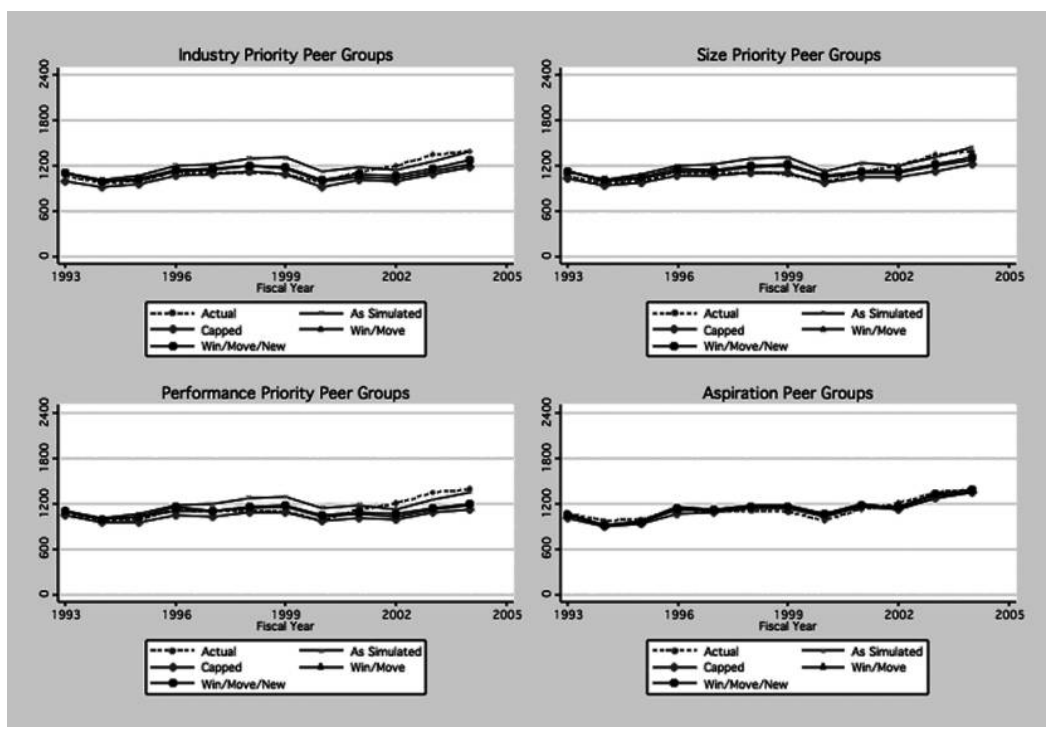

FIG. 9.-Growth of simulated median salary plus bonus, by year 
lost when leapfrogging behavior was constrained at the 75th percentile. As for the case of total compensation, the impact of capping diminished when aspiration peer groups were used instead of similar-firm peer groups. Figure 9 shows that the use of aspiration peer groups one decile larger in market cap than the focal company was sufficient to eliminate almost all the effect of capping at the median of the salary/bonus distribution over time.

The differing results obtained from the use of normative and from aspiration peer groups arise most obviously because leapfrogging is necessarily less common when aspiration peer groups are used and the benchmark distribution is thereby shifted upward. This fact is of great importance and highlights the dual mechanisms that can be used at the level of specific firms to pay greater compensation to an executive. Either one can locate an executive higher up in the normative benchmark distribution or one can raise the mean of that distribution by composing it of higherpaid executives. The percentage of leapfroggers that we display in table 4 almost certainly does not represent the actual number of lower-paid executives who were overtly benchmarked above the 80th percentile of their named peer group distribution because many or most of their firms may have included higher-paid executives from outside the normative peer group when constructing benchmarks. The use of aspiration peer groups masks leapfrogging but amounts to the same thing for an executive who receives outsize increases relative to the executives who constitute his natural comparison group. Either way, these pay increases then have systemwide implications as they diffuse to other executives through the workings of the benchmarking system.

\section{DISCUSSION}

The process of compensation determination for executives is fundamentally relational in character. Connections are drawn among a specific set of actors and a focal executive at virtually all public corporations, and compensation outcomes for the population of CEOs are dependent on the structure of this network. However, the network that links executives through peer comparisons in the process of pay setting is different from the networks that are typically researched in economic sociology. The networks in the work of scholars such as Baker (1984), Burt (1992), and Mizruchi and Stearns (2001) represent a history of social interaction among the tied individuals and are the bases for the flow of information, trust, and other resources. In reputational models such as Podolny's (2005), the network ties are signaling devices that are widely advertised to a broader audience. In the absence of direct information about quality, economic 
American Journal of Sociology

actors seek to associate with others who (are perceived to) have high status and to avoid associating with those who (are perceived to) have low status. The pattern of reciprocated association reinforces other information to define a status hierarchy. Status becomes a signal for quality and the basis for charging a higher price and getting access to needed resources at a lower cost. In all these types of networks, the relational ties are behavioral in nature; they reflect relations that can be observed in behavior such as supply chain transactions, joint ventures, board interlocks, competitive bidding for the same customer account, or other forms of social interaction.

The relational networks underlying the executive compensation system are similar to both types of networks described above and yet have important qualitative differences as well. They are similar in that the ties involve information, they involve claims to status and quality, and they affect prices-in this case, the price of executive talent. However, the network of relations that develops from firm-level peer group decisions is not behavioral; it rests instead on the fundamentally cognitive process of classification. While behavioral bases are available (e.g., talent flows), firms select their compensation peer groups primarily on the basis of the question "Whom are we like?" These abstract claims of status equivalence differ from the ties in Podolny's reputational models in that they are not widely advertised and need not be reciprocated. It is not the recipient of the asserted link - that is, the postulated peer CEO-who approves or rejects the association as would be the case in Podolny's model, but rather the compensation committee and the board of directors. In Podolny's model, the reciprocated tie must be advertised to gain the status benefits and the economic returns that follow from status. In compensation benchmarking, the asserted and often not-reciprocated association need be known only to the compensation committee and the board. The economic returns are produced when the board accepts the appropriateness of the proposed relations and when it accepts the proposed placement of the focal CEO's compensation within this benchmark distribution.

We have no doubt that in some cases, peer group ties correspond to actual social ties (CEOs in the same industry and size class typically know each other). We also do not doubt that the selection of peers outside the normative group may have an explanation in terms of social ties; for example, a peer group may include peers from a different industry that happens to be the industry of a member of the compensation committee. ${ }^{26}$ However, the compensation information need not flow through such concrete social ties because it is available from other sources, such as, for example, the compensation consultant, or more generally through the

${ }^{26}$ This was related to us by a knowledgeable source. 
proxy reports that are freely available for all public corporations because they are filed with the SEC. The potential relevance of behavioral ties concerns the partly rhetorical process of convincing the board that the peer group is appropriate; this may be easier if a board member from a different industry argues that CEOs from that different industry are appropriate comparisons for the focal company's CEO for thus and so reasons. To repeat, behavioral ties may certainly matter in the compensationsetting process, but the peer networks themselves are abstract and potentially unreciprocated assertions about labor market equivalence.

Until recently, peer group information was not overtly used by CEOs to enhance status apart from its impact on their own compensation. While CEOs could have always included such information in corporate proxy reports, this reporting has only recently become common. That the changed behavior was a response to new regulations issued by the SEC suggests that CEOs saw no advantage and possibly a disadvantage in advertising the composition of the peer group that was being used for compensation setting. In an important sense, their actions were the opposite of the process of advertising ties that is essential to the enhancement (or degradation) of status in Podolny's model and to resulting consequences for prices, costs, and transactions. One reason for this only recently abandoned circumspection may be that wider publicity for the assertions of labor market equivalence implicit in the peer group-and in the relative placement of the focal CEO within this group-would lead not to a further rise in status as in Podolny's model, but rather to challenges of the legitimacy of these assertions by shareholders. Secrecy rather than publicity may have been in the greater interest of CEOs in the context of compensation setting because the asserted cognitive relationships were not necessarily reaffirmed by the firms of CEO peers and because these asserted relationships did not necessarily correspond to other structural criteria for defining the appropriate labor market and a CEO's appropriate place within this market.

The results of this article reinforce the importance of what Coleman (1986) referred to as "micro-to-macro" models in order to account for behavioral outcomes. The literature on executive compensation recognizes that the framework for corporate governance as it applies to executive compensation derives from tax and regulatory authorities and is therefore national in scope even as the details and effectiveness of corporate governance vary by firm. This governance process requires that compensation committees pay attention to the behavior of other firms when making their decisions. In form, the executive compensation literature is similar to much of the economic sociology literature, which generally pays attention to broad environmental context (e.g., resource dependence theory [Aldrich 1979] or Fligstein's [2002] "political-cultural" approach), and to 
American Journal of Sociology

the ways in which heterogeneous actors pay attention to the behavior of other actors in their environment (DiMaggio and Powell 1983). Coleman argued that models such as these reflect the omnipresent macro-to-micro processes that cause individual behavior to be constrained by the social environment. He further argues that the obverse micro-to-macro process, which he termed "the means by which purposive actions of individuals combine to produce a social outcome" (1986, p. 1321), is also always present in social action but is generally underdeveloped in social science theories. In the case of executive compensation, the purposive action that forms the micro-to-macro link is rent seeking on the part of individual executives. This rent seeking, when combined with individual firm-level problems in corporate governance or even when combined with random shocks, affects the environment as well as the outcomes for that individual. Corporate governance affects rent seeking, but rent seeking also affects governance in such a way that even good governance leads to higher rent extraction. A full elaboration of this feedback loop between purposive action and the environment remains underdeveloped in many other problems of long-standing interest in economic sociology (e.g., the study of merger waves), just as it does in the study of rent extraction in general and of executive compensation in particular. Other scholars (e.g., DiPrete 2007; Levy and Temin 2007; Morgan and Tang 2007) have argued that institutions matter for the evolution of the compensation structure at the lower end of the earnings distribution. In the context of the current article, we would conclude that a comprehensive explanation for inequality trends in industrial countries must involve a study of the institutional dynamics that affect both higher-earning and lower-earning occupations (see also Zhou 1993; Weeden 2002).

Lacking specific information about the peer groups that firms historically used or purported to use, we took the conservative route of imputing normatively prescribed peer groups to explore mechanisms by which the use of "legitimate" means for establishing the market wage actually can produce growing rent extraction over time. Changes in the regulatory framework after the Enron and WorldCom scandals have pressured public corporations to reveal their peer groups in yearly proxy reports, which allows more careful study of how feedback between microlevel bargaining and the environment occurs. Moreover, public knowledge of peer groups may also change the nature of this feedback loop through counter pressures to deny the legitimacy of the more "aspirational" peer assertions and, more generally, to strengthen standards for how to choose an appropriate peer group for benchmarking purposes. Pressure to limit executive compensation has increased still more following the onset of the financial crisis of 2008. Whether these events have a lasting impact on 


\section{Compensation Benchmarking}

either the process of compensation setting or its outcomes is an important question for future research.

\section{REFERENCES}

Aldrich, Howard. 1979. Organizations and Environments. Stanford, Calif.: Stanford University Press.

Ang, James S., and Gregory L. Nagel. 2006. "The Influence of Peers on CEO Pay since 1970.” Manuscript. Florida State University.

Armstrong, Christopher S., Christopher D. Ittner, and David F. Larcker. 2008. "Economic Characteristics, Corporate Governance, and the Influence of Compensation Consultants on Executive Pay Levels." Manuscript.

$\rightarrow$ Baker, Wayne E. 1984. "The Social Structure of a National Security Market." American Journal of Sociology 89:775-811.

Bebchuk, Lucian A., Alma Cohen, and Allen Ferrell. 2005. "What Matters in Corporate Governance?" Olin discussion paper no. 491. Harvard University.

Bebchuk, Lucian A., and Jesse M. Fried. 2004. Pay without Performance: The Unfulfilled Promise of Executive Compensation. Cambridge, Mass.: Harvard University Press.

$\rightarrow$ Bebchuk, Lucian A., Jesse M. Fried, and D. I. Walker. 2002. "Managerial Power and Rent Extraction in the Design of Executive Compensation." University of Chicago Law Review 69:751-846.

$\rightarrow$ Bebchuk, Lucian A., and Yaniv Grinstein. 2005. "The Growth of Executive Pay." Oxford Review of Economic Policy 21:283-303.

Bebchuk, Lucian A., Yaniv Grinstein, and Urs Peyer. 2006. "Lucky CEOs.” Working paper no. 12771. National Bureau of Economic Research. Cambridge, Mass.

Berle, Adolf A., and Gardiner C. Means. 1932. The Modern Corporation and Private Property. New York: Macmillan.

$\rightarrow$ Bertrand, Marianne, and Sendhil Mullainathan. 2001. "Are CEOS Rewarded for Luck? The Ones without Principals Are." Quarterly Journal of Economics 116:901-32.

Bizjak, John M., Michael L. Lemmon, and Lalitha Naveen. 2007. "Has the Use of Peer Groups Contributed to Higher Levels of Executive Compensation?" Manuscript. Portland State University.

$\rightarrow$ Brenner, Menachem, Rangarajan K. Sundaram, and David Yermack. 2000. "Altering the Terms of Executive Stock Options." Journal of Financial Economics 57:103-28.

$\rightarrow$ Burkhauser, Richard V., Douglas Holtz-Eakin, and Stephen E. Rhody. 1997. "Labor Earnings Mobility and Inequality in the United States and Germany during the Growth Years of the 1980s." International Economic Review 38:775-94.

Burt, Ron S. 1992. Structural Holes. Cambridge, Mass.: Harvard University Press.

Cadman, Brian, Sandy Klasa, and Steve Matsunga. 2007. "Evidence on How CEO Compensation Functions Differ between Execucomp Firms and Non-Execucomp Firms." Manuscript. Northwestern University.

$\rightarrow$ Coleman, James S. 1986. "Social Theory, Social Research, and a Theory of Action." American Journal of Sociology 91:1309-35.

Cook, F. W. 1981. "The Compensation Director and the Board's Compensation Committee." Compensation and Benefits Review 13 (2): 37-41.

$\rightarrow$ Core, John E., Robert W. Holthausen, and David F. Larcker. 1999. "Corporate Governance, Chief Executive Officer Compensation, and Firm Performance.” Journal of Financial Economics 51:371-406.

Crystal, Graef S. 1991. In Search of Excess: The Overcompensation of American Executives. New York: Norton.

$\rightarrow$ Davis, Gerald F. 2005. "New Directions in Corporate Governance." Annual Review of Sociology 31:143-62. 


\section{American Journal of Sociology}

$\rightarrow$ Demsetz, Harold, and Kenneth Lehn. 1985. "The Structure of Corporate Ownership: Causes and Consequences." Journal of Political Economy 93:1155-77.

$\rightarrow$ DiMaggio, Paul J., and Walter W. Powell. 1983. "The Iron Cage Revisited: Institutional Isomorphism and Collective Rationality." American Sociological Review 48:147-60.

$\rightarrow$ DiPrete, Thomas A. 2007. "What Has Sociology to Contribute to the Study of Inequality Trends? A Historical and Comparative Perspective." American Behavioral Scientist 50:603-18.

$\rightarrow$ DiPrete, Thomas A., and Greg M. Eirich. 2006. "Cumulative Advantage as a Mechanism for Inequality: A Review of Theoretical and Empirical Developments." Annual Review of Sociology 32:271-97.

$\rightarrow$ DiPrete, Thomas A., Dominique Goux, Eric Maurin, and Amelie Quesnel-Vallee. 2006. "Work and Pay in Flexible and Regulated Labor Markets: A Generalized Perspective on Institutional Evolution and Inequality Trends in the U.S. and Europe." Research in Social Stratification and Mobility 24:311-32.

$\rightarrow$ Ebbinghaus, Bernard, and Bernard Kittel. 2005. "European Rigidity versus American Flexibility? The Institutional Adaptability of Collective Bargaining." Work and Occupations 32:163-95.

$\rightarrow$ Fama, Eugene F. 1980. "Agency Problems and the Theory of the Firm." Journal of Political Economy 88:288-307.

$\rightarrow$ Faulkender, Michael W., and Jun Yang. 2010. "Inside the Black Box: The Role and Composition of Compensation Peer Groups." Journal of Financial Economics 96: 257-70.

Fligstein, Neil. 1990. The Transformation of Corporate Control. Cambridge, Mass.: Harvard University Press.

- 2002. The Architecture of Markets: An Economic Sociology of Twenty-first Century Capitalist Societies. Princeton, N.J.: Princeton University Press.

$\rightarrow$ Fligstein, Neil, and Jennifer Choo. 2005. "Law and Corporate Governance." Annual Review of Law and Social Science 1:61-84.

$\rightarrow$ Fligstein, Neil, and Luke Dauter. 2007. "The Sociology of Markets." Annual Review of Sociology 33:105-28.

Frank, Robert H., and Philip J. Cook. 1995. The Winner Take All Society: How More and More Americans Compete for Ever Fewer and Bigger Prizes, Encouraging Economic Waste, Income Inequality, and an Impoverished Cultural Life. New York: Free Press.

$\rightarrow$ Gabaix, Xavier, and Augustin Landier. 2008. "Why Has CEO Pay Increased So Much?” Quarterly Journal of Economics 123:49-100.

Goldin, Claudia Dale, and Lawrence F. Katz. 2008. The Race between Education and Technology. Cambridge, Mass.: Harvard University Press.

$\rightarrow$ Gompers, Paul, Joy Ishii, and Andrew Metrick. 2003. "Corporate Governance and Equity Prices." Quarterly Journal of Economics 118:107-55.

$\rightarrow$ Gould, Roger. 2002. "The Origins of Status Hierarchies: A Formal Theory and Empirical Test." American Journal of Sociology 107:1143-78.

$\rightarrow$ Hall, Brian J., and Jeffrey B. Liebman. 1998. "Are CEOS Really Paid like Bureaucrats?" Quarterly Journal of Economics 113:653-91.

$\rightarrow$ Hall, Brian J., and Kevin J. Murphy. 2003. "The Trouble with Stock Options.” Journal of Economic Perspectives 17:49-70.

$\rightarrow$ Han, Shin-Kap. 1994. "Mimetic Isomorphism and Its Effect on the Audit Services Market." Social Forces 73:637-64.

$\rightarrow$ Hermalin, Benjamin E. 2005. "Trends in Corporate Governance." Journal of Finance 60:2351-84.

Hicks, John. 1948. The Theory of Wages. New York: P. Smith.

Himmelberg, Charles P., and R. Glenn Hubbard. 2000. "Incentive Pay and the Market for CEOs: An Analysis of Pay-for-Performance Sensitivity.” Working paper. Columbia University, Business School. 


\section{Compensation Benchmarking}

$\rightarrow$ Holmstrom, Bengt, and Steven N. Kaplan. 2001. "Corporate Governance and Takeovers in the US: Making Sense of the 80s and 90s." Journal of Economic Perspectives $15: 121-44$

. 2003. "The State of U.S. Corporate Governance: What's Right and What's Wrong?" Journal of Applied Corporate Finance 15 (2): 8-20.

$\rightarrow$ Jensen, M. C., and Kevin J. Murphy. 1990. "Performance Pay and Top-Management Incentives." Journal of Political Economy 98:225-64.

Katz, Larry F., and David H. Autor. 1999. "Changes in the Wage Structure and Earnings Inequality." Pp. 1463-1555 in Handbook of Labor Economics, vol. 3. Edited by Orley Ashenfelter and David Card. Amsterdam: North-Holland.

$\rightarrow$ Kenworthy, Lane. 2007. "Inequality and Sociology." American Behavioral Scientist 50: 584-602.

Khurana, R. 2002. Searching for a Corporate Savior: The Irrational Quest for Charismatic CEOs. Princeton, N.J.: Princeton University Press.

$\rightarrow$ Kilduff, Martin, and David Krackhardt. 1994. "Bringing the Individual Back In: A Structural Analysis of the Internal Market for Reputation in Organizations." Academy of Management Journal 37:87-108.

Kuhnen, Camelia M., and Jeffrey Zwiebel. 2007. "Executive Pay, Hidden Compensation and Managerial Entrenchment." Manuscript. Northwestern University.

Levy, Frank, and Peter Temin. 2007. "Inequality and Institutions in 20th Century America." Working paper no. 13106. National Bureau of Economic Research, Cambridge, Mass.

Marshall, A. 1920. The Principles of Economics, 8th ed. London: Macmillan.

$\rightarrow$ Maurin, Eric, and Fabien Postel-Vinay. 2005. "The European Job Security Gap." Work and Occupations 32:229-52.

$\rightarrow$ Meyer, John W., and Brian Rowan. 1977. "Institutionalized Organizations: Formal Structure as Myth and Ceremony." American Journal of Sociology 83:340-63.

$\rightarrow$ Mizruchi, Mark S., and Linda B. Stearns. 2001. "Getting Deals Done: The Use of Social Networks in Bank Decision-Making." American Sociological Review 66: $647-71$.

Morgan, Stephen L., and Zun Tang. 2007. "Social Class and Workers' Rent, 1983-2001." Research in Social Stratification and Mobility 25:273-93.

$\rightarrow$ Murphy, Kevin J. 2002. "Explaining Executive Compensation: Managerial Power versus the Perceived Cost of Stock Options." University of Chicago Law Review 69: 847-69.

$\rightarrow$ Murphy, Kevin J., and Ján Zábojník. 2004a. "CEO Pay and Appointments: A MarketBased Explanation for Recent Trends." American Economic Review 94:192-96.

_. 2004b. "Managerial Capital and the Market for CEOs." Working paper. University of Southern California, Marshall School of Business.

Nagel, Gregory L. 2007. "Persistently Underpaid CEOs and Their Influence on Pay Benchmarks." Manuscript. Mississippi State University.

_. 2008. "Why Has CEO Pay Increased So Much? A Comment." Working paper. Mississippi State University.

Nelson, R. L., and W. P. Bridges. 1999. Legalizing Gender Inequality: Courts, Markets, and Unequal Pay for Women in America. Cambridge: Cambridge University Press.

$\rightarrow$ Oyer, Paul. 2004. "Why Do Firms Use Incentives That Have No Incentive Effects?" Journal of Finance 59:1619-49.

Patton, A. 1951. "Current Practices in Executive Compensation." Harvard Business Review 29:56-64.

Pittinsky, Matthew, and Thomas A. DiPrete. 2010. "The Relational Structure of Executive Pay." Manuscript. Arizona State University.

Podolny, Joel M. 2005. Status Signals. Princeton, N.J.: Princeton University Press.

$\rightarrow$ Porac, Joseph F., James B. Wade, and Timothy G. Pollock. 1999. "Industry Categories 


\section{American Journal of Sociology}

and the Politics of the Comparable Firm in CEO Compensation." Administrative Science Quarterly 44:112-44.

Reda, James F., Stewart Reifler, and Laura G. Thatcher. 2008. The Compensation Committee Handbook, 3d ed. New York: Wiley.

$\rightarrow$ Roberts, D. R. 1956. "A General Theory of Executive Compensation Based on Statistically Tested Propositions." Quarterly Journal of Economics 70:270-94.

$\rightarrow$ Rosen, Sherwin. 1981. "The Economics of Superstars." American Economic Review 71:845-58.

$\rightarrow$ Rosenbaum, James E. 1979. "Tournament Mobility: Career Patterns in a Corporation." Administrative Science Quarterly 24:220-41.

$\rightarrow$ Short, Helen. 1994. "Ownership, Control, Financial Structure, and the Performance of Firms." Journal of Economic Surveys 8:203-49.

$\rightarrow$ Simon, H. A. 1957. "The Compensation of Executives." Sociometry 20:32-35.

$\rightarrow$ Sorensen, Aage B. 1996. "The Structural Basis of Social Inequality." American Journal of Sociology 101:1333-65.

$\rightarrow$. 2000. "Toward a Sounder Basis for Class Analysis." American Journal of Sociology 105:1523-58.

Useem, M. 1993. Executive Defense: Shareholder Power and Corporate Reorganization. Cambridge, Mass.: Harvard University Press.

$\rightarrow$ Wade, J. B., J. F. Porac, and T. G. Pollock. 1997. "Worth, Words, and the Justification of Executive Pay." Journal of Organizational Behavior 18:641-64.

$\rightarrow$ Weeden, Kim A. 2002. "Why Do Some Occupations Pay More than Others? Social Closure and Earnings Inequality in the United States." American Journal of Sociology 108:55-101.

Westphal, James D., and Edward J. Zajac. 1994. "Substance and Symbolism in CEOs' Long-Term Incentive Plans." Administrative Science Quarterly 39:367-90.

$\rightarrow$. 1998. "The Symbolic Management of Stockholders: Corporate Governance Reforms and Shareholder Reactions." Administrative Science Quarterly 43:127-53.

$\rightarrow$. 2001. "Decoupling Policy from Practice: The Case of Stock Repurchase Programs." Administrative Science Quarterly 46:202-28.

$\rightarrow$ Yermack, David. 1997. "Good Timing: CEO Stock Option Awards and Company News Announcements.” Journal of Finance 52:449-76.

$\rightarrow$ Zhou, Xueguang. 1993. "Occupational Power, State Capacities, and the Diffusion of Licensing in the American States: 1980-1950.” American Sociological Review 58: $536-52$. 